\title{
BIBLIOGRAPHY OF CANADIAN EDUCATIONAL HISTORY / BIBLIOGRAPHIE D'HISTOIRE DE L'ÉDUCATION CANADIENNE
}

This issue continues the bibliography on Canadian educational history and related fields most recently listed in Volume 8, number 1 (Spring 1996).

Nous poursuivons ici notre bibliographie sur l'histoire de l'éducation au Canada et sur certains domaines connexes, bibliographie dont la dernière mise à jour fut effectuée dans le volume 8, numéro 1 (printemps 1996).

Les périodiques qui ont fait l'objet d'un dépouillement systématique comprennent/journals systematically searched include: Acadiensis, Alberta History, Archivaria, Atlantis, BC Studies, British Journal of Educational Studies, Canadian and International Education, Canadian Bulletin of Medical History, Canadian Ethnic Studies/Études ethniques au Canada, Canadian Geographer, Canadian Historical Review, Canadian Journal of Higher Education/La revue canadienne d'enseignement supérieur, Canadian Journal of Political and Social Theory, Canadian Journal of Sociology, Canadian Review of Sociology and Anthropology, Canadian Woman Studies/Les cahiers de la femme, Histoire sociale/Social History, History of Education (England), History of Education Quarterly, History of Education Review (Australian and New Zealand History of Education Society), History of Higher Education Annual, Interchange, JET: The Journal of Educational Thought/Revue de la pensée éducative, Journal of Canadian Studies/Revue d'études canadiennes, Journal of the Canadian Historical Association/Revue de la Société historique du Canada, Labour/Le Travail, McGill Journal of Education, Manitoba History, Ontario History, Oxford Review of Education, Prairie Forum, Queen's Quarterly, Revue d'histoire de l'Amérique française, Saskatchewan History, Teachers College Record, Urban History Review.

Acker, Sandra. “Caring as Work for Women Educators.” In Challenging Professions: Historical and Contemporary Perspectives on Women's Professional Work, ed. Elizabeth Smyth, Sandra Acker, Paula Bourne, and Alison Prentice. Toronto: University of Toronto Press, 1999, 277-95.

Adams, Annmarie. "“Archi-ettes' in Training: The Admission of Women to McGill's School of Architecture.” Society for the Study of Architecture in Canada Bulletin 21, 3 (1996): 70-73.

Adnett, Nick, and Peter Davies. "Education as a Positional Good: Implications for Market-Based Reforms of State Schooling.” British Journal of Educational Studies 50, 2 (June 2002): 189-205.

Ali, Jennifer, and Edward Grabb. "Ethnic Origin, Class Origin, and Educational Attainment in Canada: Further Evidence on the Mosiac Thesis.” Journal of Canadian Studies/Revue d'études canadiennes 33, 1 (1998): 3-21.

(C) Historical Studies in Education/Revue d'histoire de l'éducation 14, 2 (2002): 319-64 
Andrew, Sheila. "Mother's Helper? Factors affecting the feminization of teaching in New Brunswick Acadian Public Schools, 1861-1881.” In L'Acadie au féminin: un regard multidisciplinaire sur les Acadiennes et les Cadiennes. Sous la direction de Maurice Basque et al. Moncton: Université de Moncton, 2000.

Andrew, Sheila. "Selling Education: The Problems of Convent Schools in Acadian New Brunswick, 1858-1886.” Canadian Catholic Historical Association Historical Studies 62 (1996): 15-32.

Andrich, Sheila. "The History of Education in Manitoba: A Bibliography, 1993-1998.” Manitoba History 36 (1998/1999): 52-53.

Anisef, Paul, Paul Axelrod, Etta Baichman-Anisat, Carl James, and Anton Turrittin in collaboration. Opportunity and Uncertainty: Life Course Experiences of the Class of '73. Toronto: University of Toronto Press, 2000.

Aper, Jeffrey P. "Steerage from a Distance: Can Mandated Accountability Systems Really Improve Schools?” Journal of Educational Thought 36, 1 (April 2002): 7-26.

Archibald, Jo-ann. "Locally Developed Native Studies Curriculum: An Historial and Philosophical Pedagogy.” In First Nations Education in Canada: The Circle Unfolds, ed. Jean Barman and Marie Battiste. Vancouver: University of British Columbia Press, 1995, 288-312.

Aubin, Paul. Les communautés religieuses et l'édition du manuel scolaire au Québec, 1765-1964. Sherbrooke: Ex libris, 2001.

Aubin, Paul, et Michel Simard. Les manuels scolaires dans la correspondance du Département de l'instruction publique, 1842-1899: inventaire. Sherbrooke: Éditions Ex-Libris, coll. “Cahiers du GRÉLQ”, no. 4, 1997.

Aunger, E.A. "Dispersed minorities and segmental autonomy: Frenchlanguage school boards in Canada.” Nationalism \& Ethnic Politics 2, 2 (1996): 191-215.

Austin, Barbara, ed. Capitalizing Knowledge: Essays on the History of Business Education in Canada. Toronto: University of Toronto Press, 2000.

Axelrod, Paul. "Challenges to Liberal Education in an Age of Uncertainty." Historical Studies in Education/Revue d'histoire de l'éducation 10, 1/2 (1998): 1-19.

Axelrod, Paul. "Higher Education in Canada and the United States: Exploring the Roots of Difference." Historical Studies in Education/Revue d'histoire de l'éducation 7, 2 (Fall/automne 1995), 141-75. 
Axelrod, Paul. "Historical Writing and Canadian Education from the 1970s to the 1990s.” History of Education Quarterly 36, 1 (Spring 1996): 19-38.

Axelrod, Paul. "McGill University on the Landscape of Canadian Higher Education: Historical Reflections." Higher Education Perspectives 1 (1996-7): 199-34; reprinted in Fontanus, Fall 1998, 117-33.

Axelrod, Paul. The Promise of Schooling: Education in Canada, 1800-1914. Toronto: University of Toronto Press, 1997.

Axelrod, Paul. "Romancing the Past: Nostalgic Conservatism, the Great Brain Robbery, and the History of Education.” In Historical Perspectives on Educational Policy in Canada: Issues, Debates and Case Studies, ed. Eric W. Ricker and B. Anne Wood. Toronto: Canadian Scholars' Press, 1995, 61-74.

Axelrod, Paul. "Spying on the Young in Depression and War: Students, Youth Groups and the RCMP, 1935-1492." Labour/Le Travail 35 (Spring/printemps 1995): 43-63.

Axelrod, Paul. Values in Conflict: The University, the Marketplace, and the Trials of Liberal Education. Montreal and Kingston: McGill-Queen's University Press, 2002.

Axelrod, Paul and P. Anisef. "Transition, the Life Course and the Class of '73." In Youth in Transition: Perspectives on Research and Policy, ed. Burt Galaway and Joe Hudson. Toronto: Thompson Educational Pub., 1996, 142-51.

Baines, Carol. "Professor Elizabeth Govan: An Outsider in Her Own Community.” In Challenging Professions: Historical and Contemporary Perspectives on Women's Professional Work, ed. Elizabeth Smyth, Sandra Acker, Paula Bourne, and Alison Prentice. Toronto: University of Toronto Press, 1999, 44-64.

Baker, Melvin. Celebrate Memorial! a pictorial history of Memorial University of Newfoundland. St. John's: Memorial University of Newfoundland, 1999.

Baker, Melvin. "Memorial University of Newfoundland: a retrospective." Luminus 25 (Fall 1999): 10-11, 23.

Baker, Melvin. "Presidents of Memorial University College and Memorial University of Newfoundland, 1925-1999.” Newfoundland Quarterly 93 (Fall 1999): 2-5.

Baker, Melvin. "The Establishment of Memorial's Institute of Social and Economic Research in 1961.” Newfoundland Quarterly 92, 3 (Winter 1999): 21-25.

Baksh, Ishmael J., et al., eds. Studies in Newfoundland Education and Society. St. John’s: Memorial University of Newfoundland, 2000. 
Balders, Bernd, and Meenaz Kassam. “'Make Me Truthful, Good and Mild’: Values in $19^{\text {th }}$ Century Ontario Schoolbooks.” Canadian Journal of Sociology 21, 3 (1996): 327-58.

Barman, Jean. “Aboriginal Education at the Crossroads: The Legacy of Residential Schools and the Way Ahead.” In Visions of the Heart: Canadian Aboriginal Issues, ed. David Alan Long and Olive Patricia Dickason. Toronto: Harcourt Brace \& Company, Canada, 1996, 271-303.

Barman, Jean. "Families vs. Schools: Children of Aboriginal Descent in British Columbia Classrooms of the Late Nineteenth Century.” In Family Matters: Papers in Post-Confederation Canadian Family History, ed. Ed Montigny and Lori Chambers. Toronto: Canadian Scholars’ Press, 1998, 73-79.

Barman, Jean. “'I Walk my own Track in Life \& No Mere Male can Bump me Off It’: Constance Lindsay Skinner and the Work of History.” In Creating Historical Memory: English Canadian Women and the Work of History, ed. Beverley Boutilier and Alison Prentice. Vancouver: UBC Press, 1997, 129-68.

Barman, Jean. "Schooled for Inequality: The Education of British Columbia Aboriginal Children." In Children, Teachers and Schools in the History of British Columbia, ed. Jean Barman, Neil Sutherland, and J. Donald Wilson. Calgary: Detselig Enterprises, 1995, 57-80.

Barman, Jean. "Separate and Unequal: Indian and White Girls at All Hallows School, 1884-1920." In Children, Teachers, and Schools in the History of British Columbia , ed. Jean Barman, Neil Sutherland, and J. Donald Wilson. Calgary: Detselig Enterprises, 1995, 337-58.

Barman, Jean. "Vancouver’s Forgotten Entrepreneurs: Women Who Ran Their Own Schools,” British Columbia Historical News 31, 4 (Fall 1998), 21-9.

Barman, Jean, Neil Sutherland, and J. Donald Wilson, eds. Children, Teachers and Schools in the History of British Columbia. Calgary: Detselig, 1995.

Battiste, Marie, and Jean Barman, eds. First Nations Education in Canada: The Circle Unfolds. Vancouver: University of British Columbia Press, 1995.

Beagan, Brenda L. ““Even if I don’t know what I’m doing I can make it look like I know what I'm doing': Becoming a Doctor in the 1990's.” Canadian Review of Sociology and Anthropology 38, 3 (August 2001): 275-92.

Bédard, Eric. “L’idéologie syndicale étudiante: du discours à la pratique: le cas de l'AGEUM (1960-1969)," Bulletin du Regroupement des chercheurs-chercheures en histoire des travailleurs et travailleuses du Québec 21, 1 (hiver 1995): 13-32. 
Bélanger, Damien-Claude. "L’histoire intellectuelle du Canada et du Québec: bibliographie sélective.” Mens 1, 2 (printemps 2001): 189-223.

Bélanger, Nathalie, Clermont Gauthier, et Maurice Tardif. "Ruptures et continuités dans l'évolution des programmes de mathématiques de 1861 à 1981: l'ampleur d'une réforme.” Historical Studies in Education/Revue d'histoire de l'éducation 7, 1 (1995): 1-44.

Bélanger, Nathalie. “L’éducation spéciale à l’épreuve de l’histoire,” Historical Studies in Education/Revue d'histoire de l'éducation 9, 1 (Spring/printemps 1997): 21-45.

Bell, J. Milton. Hoofprints to Reprints: The History of the Department of Animal Husbandry, Animal Science and Animal and Poultry Science, University of Saskatchewan, 1909-1989. Saskatoon: College of Agriculture, University of Saskatchewan, 1996.

Benson, William. "School Psychology in British Columbia.” Canadian Journal of School Psychology 16, 2 (2001): 85-86.

Bercuson, David J., Robert Bothwell, and J.L. Granatstein. Petrified Campus: The Decline of Canada's Universities. Mississauga: Random House, 1997.

Bernatchez, Stéphane, et Guy Bourgeault. “La prise en compte de la diversité culturelle et religieuse à l'école publique et l' 'obligation

d'accommodement' - Aperçu des législations et des jurisprudences au Canada, aux États-Unis, en France et en Grande-Bretagne.” Canadian Ethnic Studies/Études ethniques au Canada 31, 1 (1999): 159-71.

Billard, J. Gordon. "Early Newfoundland Schools and Curriculum.” Newfoundland Quarterly 34, 4 (Spring/Summer 2000): 21-28.

Bloomfield, Elizabeth. Waterloo Township Schools, 1842-1972. Guelph, Ontario: Caribou Imprints, 1995.

Bogaard, Paul A. "Science within the liberal arts: Mount Allison and the Maritime universities.” In Liberal Education and the Small University in Canada, ed. Christine Storm. Montreal and Kingston: McGill-Queen's University Press, 1996: 89-104.

Bogaard, Paul A. "The Presbyterian contribution to higher education: teaching science in Maritime universities.” In The Contribution of Presbyterianism to the Maritime Provinces of Canada, ed. Charles H. H. Scobie and G. A. Rawlyk. Montreal and Kingston: McGill-Queen’s University Press, 1997, 35-53; 217-20.

Bordin, Ruth. Women at Michigan: The “Dangerous Experiment," 1870s to the Present. Ann Arbor: University of Michigan Press, 1999.

Borrell, Helen. “The Fairbridge Farm School.” British Columbia Historical News 29, 1 (1995/96): 17-23. 
Borst, Charlotte G. "Choosing the Student Body: Masculinity, Culture, and the Crisis of Medical School Admissions, 1920-1950.” History of Education Quarterly 42, 2 (Summer 2002): 181-214.

Bourgeois, Angela. "Une école toute neuve ouvre ses portes.” Brins d'histoire. Cahier de la Société historique de Grande-Digue 3 (nov. 1995): 5-18.

Bourgeois, Florence. "Les anciennes écoles." Brins d'histoire. Cahier de la Société historique de Grande-Digue 3 (nov. 1995): 19-29.

Brackin, Patricia. "Assessing Engineering Education: An Industrial Analogy.” The International Journal of Engineering Education 18, 2 (2002): 151-6.

Bradbury, Bettina. "Feminist Historians and Family History in Canada in the 1990s.” Journal of Family History 25, 3 (July 2000): 362-83. (Review essay)

Bradley, Richard, and Paul Lewis. Ridley: A Canadian School. Erin: Boston Mills Press, 2000.

Brien, André. 150 ans d'éducation à Joliette, 1846-1996. Joliette, Québec: A. Brien, 1996.

British Columbia Ministry of Education. Special Programs Branch. Teaching Students With Autism: A Resource Guide For Schools. Victoria: The Ministry, 2000.

Brodeur, Raymond, et Brigitte Caulier, dir. Enseigner le catéchisme: autorités et institutions, XVIe-XXe siècles. Québec/Paris: Presses de l'Université Laval/Éditions du Cerf, 1997.

Brooks, Kevin. "Liberal Education on the Great Plains: American Experiments, Canadian Flirtations, 1930-1950.” Great Plains Quarterly 17, 2 (1997): 103-17.

Brooks, Kevin. "Writing instruction or textual studies? Professionalism and the junior curriculum at the University of Manitoba, 1909-1935.” Textual Studies in Canada 10, 1 (1998): 157-76.

Brosseau, Marc. "L’architecture de la géographie scolaire québécoise: 18041960.” Cahiers de géographie du Québec 43, 120 (déc. 1999): 561-84.

Brown, Helen. "Gender and Space: Constructing the Public School Teaching Staff in Nanaimo, 1891-1914.” BC Studies 105 and 106 (Spring/Summer 1995): 59-79.

Bruneau, William A. "Music and Marginality: Jean Coulthard and the University of British Columbia, 1947-1973.” In Challenging Professions: Historical and Contemporary Perspectives on Women's 
Professional Work, ed. Elizabeth Smyth, Sandra Acker, Paula Bourne, and Alison Prentice. Toronto: University of Toronto Press, 1999, 96-116.

Bruno-Jofré, Rosa. “Citizenship and Schooling in Manitoba, 1918-1945.” Manitoba History 36 (1998/1999): 26-36.

Bruno-Jofré, Rosa. "Lifting the Veil: The Founding of the Missionary Oblate Sisters of the Sacred Heart and Mary Immaculate in Manitoba." Historical Studies in Education/Revue d'histoire de l'éducation 9, 1 (1997): 1-20.

Bruno-Jofré, Rosa. "Manitoba Schooling in the Canadian Context and the Building of a Polity: 1919-1971.” Canadian and International Education 28, 2 (Dec. 1999): 99-128.

Bruno-Jofré, Rosa, and Dick Henley. "Public Schooling in English Canada: Addressing Difference in the Context of Globalization.” Canadian Ethnic Studies/Études Ethniques au Canada 32, 1 (2000): 38-53.

Bruno-Jofré, Rosa, and Lois Grieger, eds. Papers on Contemporary Issues in Education Policy and Administration in Canada: A Foundations Perspective. [Winnipeg]: Monographs in Education, XXIII, University of Manitoba, 1996.

Bucci, Terri Teal. "Paradigm Parallel Pedagogy: The Significance of Parallel Paradigms.” Journal of Educational Thought 36, 1 (April 2002): 69-85.

Buchbinder, Howard, and Pinayur Rajagopal. "Canadian Universities: The Impact of Free Trade and Globalization.” Higher Education 31, 3 (1996): 283-99.

Bullock, Patricia, Valerie Park, Jennifer Snow, and Encama Rodriguez. "Redefining Interdisciplinary Curriculum: A Journey of Collaboration and Change in Secondary Teacher Education.” Interchange 33, 2 (2002): 159-82.

Burban, Christelle. “L’engagement décisif et inégal de l’État québécois en faveur de la protection de l'enfance: l'École d'industrie de Notre-Dame de Montfort (1883-1913).” Bulletin d'histoire politique 6, 2 (hiver 1998): 40-47.

Burke, Sara Z. ““Being Unlike Man’: Challenges to Co-education at the University of Toronto, 1884-1909.” Ontario History 93, 1 (2001): 11-31.

Burke, Sara Z. "New Women and Old Romans: Co-education at the University of Toronto, 1884-95.” Canadian Historical Review 80, 2 (June 1999): 219-41.

Burke, Sara Z. Seeking the Highest Good: Social Service and Gender at the University of Toronto, 1888-1937. Toronto: University of Toronto Press, 1996. 
Burton, Dorothy. "The Early Years: Women’s Athletics at McMaster University (1948-1952).” Canadian Association for Health, Physical Education and Recreation (Winter 1994): 9-13.

Buxton, William J. “Time, Space, and the Place of Universities in Western Civilization: Harold Innis’ Plea.” International Journal of Canadian Studies 15 (Spring 1997): 37-48.

Cadotte, Robert, et Colette Noël. L'école Notre-Dame-de-l'Assomption, Louis-Jolliet. Montréal: Commission scolaire de Montréal, 2001.

Cahill, Barry. "Dismissal of a President: The Ordeal of Carleton Stanley at Dalhousie University, 1943-1945.” Acadiensis 31, 1 (Autumn 2001): 76102.

Cahill, Barry. "The Higher Educator as 'Intellocrat': The Odyssey of Carleton Stanley.” Historical Studies in Education 14, 1 (Spring 2002): 67-91.

Cahn, Susan K. "Crushes, Competition, and Closets: The Emergence of Homophobia in Women's Physical Education.” In Women, Sport and Culture, ed. Susan Birrell and Cheryl L. Cole. (Champaign, IL: Human Kinetics Publishers, 1994): 327-40.

Cameron, James D. For the People: A History of St. Francis Xavier University. Montreal and Kingston: McGill-Queen's University Press, 1996.

Cameron, James D. "From intimacy to detachment: the history of relations between St. Francis Xavier University and the Diocese of Antigonish to 1970.” Journal of the Royal Nova Scotia Historical Society 4 (2001): 7083.

Carney, Robert. “Aboriginal Residential Schools Before Confederation: The Early Experience.” Canadian Catholic Historical Association Historical Studies 61 (1995): 13-40.

Carney, Robert. The Education Canons of the Roman Catholic Church and Roman Catholic Schooling in Alberta. Edmonton: Alberta Catholic School Trustees Association, 1995.

Cartwright, Don. "Expansion of French Language Rights in Ontario, 19681993: The Uses of Territoriality in a Policy of Gradualism.” Canadian Geographer 40, 3 (Autumn 1996): 238-57.

Caulier, Brigitte. "Enseigner la religion dans le système scolaire confessionnel au Québec (XIXe-XXe siècles).” Dans Enseigner le catéchisme: autorités et institutions, XVIe-XXe siècles, dir. Raymond Brodeur et Brigitte Caulier. Québec/Paris: Presses de l’Université Laval/Éditions du Cerf, 1997, 265-84. 
Cavanagh, Sheila L. "The Heterosexualization of the Ontario Woman Teacher in the Postwar Period." Canadian Woman Studies/les cahiers de la femme 18, 1 (Spring 1998): 65-69.

Cavar, Tomislava. "The Role of Male Physical Educators and Administrators in the Advancement of Female Students' Physical Educational Experiences.” Canadian Woman Studies 21, 3 (Winter 2002): 100-106.

Cecillon, Jack. "Turbulent Times in the Diocese of London: Bishop Fallon and the French-Language Controversy, 1910-18.” Ontario History 87, 4 (Dec. 1995): 369-95.

Centre for Higher Education Research and Development. Learning from Our Past: The History of Higher Education Development in Canadian Universities. Winnipeg, Man.: University of Manitoba, 1997.

Chalmers, F. Graeme. “Teaching Drawing in $19^{\text {th }}$-century Canada. Why?” In Curriculum, Culture, and Art Education, ed. Kerry J. Freedman and Fernando Hernández y Hernández. Albany, NY: SUNY Press, 1998, 4758, 199-201.

Chalmers, John W. “Who was Alberta’s First Teacher?” Alberta History 43, 4 (Autumn 1995): 13-15.

Charland, Jean-Pierre. “L’éducation par l'exemple: le contrôle des comportements des instituteurs et des intitutrices des écoles publiques québécoises, 1842-1897.” Dans Érudition, humanisme et savoire, dir. Yves Roby et Nive Voisine. Sainte-Foy: Presses de l’Université Laval, 1996, 195-215.

Charland, Jean-Pierre. L'entreprise éducative au Québec, 1840-1900. SainteFoy: Les Presses de l’Université Laval, 2000.

Charland, Jean-Pierre. "L’histoire de l'éducation au Québec: regard sur la production récente.” Revue d'histoire de l'Amérique française 50, 4 (1997): 599-614.

Chevrier, Marc. "Le chantier abandonné de 1964: les onze propositions de Daniel Johnson, père, sur l'éducation.” Les cahiers d'histoire du Québec au XXe siècle 7 (printemps 1997): 164-78.

Choquette, Robert. The Oblate Assault on Canada's Northwest. Ottawa: University of Ottawa Press, 1995.

Chown, Diana. “Alice Chown's Criticism of Deaconess Education in the Methodist Church, edited, and with an introductory note by Diana Chown." Historical Studies in Education/Revue d'histoire de l'éducation 8, 1 (Spring/printemps 1996): 82-99.

Chrisjohn, Roland, and Shari Young. The Circle Game: Shadows and Substance in the Indian Residential School Experience in Canada. Penticton: Theytus Books, 1997. 
Christian, William. "Canada’s Fate: Principal Grant, Sir George Parkin and George Grant.” Journal of Canadian Studies/Revue d'études canadiennes 34, 4 (1999): 88-104.

Cinq-Mars, Jean. Histoire du Collège Sainte-Marie de Montréal, 1848-1969. Montréal: Hurtubise HMH, 1998.

50 ans de souvenirs, 1946-1996: école centrale de Bertrand. S.l.: École OlaLéger, 1996. (N.B.)

Clarke, Bill. Historic Dalhousie: Images of Our Past. Halifax: Nimbus Publishing, 2001.

Cliche, Marie-Aimée. “'Est-ce une bonne méthode pour élever les enfants?’ Le débat sur les punitions corporelles dans les courrieurs du coeur au Québec de 1925 à 1969.” Canadian Historical Review 82, 4 (Dec. 2001): 662-89.

Cliche, Marie-Aimée. “'Qui bene amat bene castigat’: Le débat pédagogique sur les punitions corporelles dans les revues pédagogiques du Québec, 1857-1964.” Historical Studies in Education/Revue d'histoire de l'éducation 11, 2 (1999): 147-69.

Clubine, Christopher. "Motherhood and Public Schooling in Victorian Toronto.” Ontario History 88, 3 (Sept. 1996): 169-84.

Collins, Alice, and Patricia Langlois. "'I knew I would have to make a choice': Voices of Women Teachers from Newfoundland and Labrador." Newfoundland Studies 11, 2 (Fall 1995): 308-28.

Comacchio, Cynthia. “"A Postscript for Father’: Defining a New Fatherhood in Interwar Canada.” Canadian Historical Review 78, 3 (Sept. 1997): 385-408.

Comacchio, Cynthia. "Inventing the Extracurriculum: High School Culture in Interwar Ontario.” Ontario History 93, 1 (2001): 33-56.

Comacchio, Cynthia. “"The History of Us’: Social Science, History, and the Relations of the Family in Canada.” Labour/Le Travail 46 (Fall 2000): 167-220.

Conrad, Margaret. "'But such is life': growing up in Nova Scotia in the interwar years.” Journal of the Royal Nova Scotia Historical Society 2 (1999): 1-26.

Cook, Sharon Anne. “'Earnest Christian Women, Bent on Saving Our Canadian Youth': The Ontario Woman's Christian Temperance Union and Scientific Temperance Instruction, 1881-1930.” Ontario History 86, 3 (Sept. 1995): 249-68.

Cook, Sharon Anne. “Through Sunshine and Shadow”: The Woman's Christian Temperance Union, Evangelicalism, and Reform in Ontario, 
1874-1930. Montreal and Kingston: McGill-Queen's University Press, 1995.

Cook, Sharon Anne, et al., eds. Framing Our Past: Constructing Canadian Women's History in the Twentieth Century. Montreal and Kingston: McGill-Queen's University Press, 2001.

Corbett, Mike. "A Protracted Struggle: Rural Resistance and Normalization in Canadian Educational History." Historical Studies in Education/Revue d'histoire de l'éducation 13, 1 (Spring 2001): 19-48.

Corbo, Claude, avec la collaboration de Jean-Pierre Couture. Repenser l'école: une anthologie des débats sur l'éducation au Québec de 1945 au rapport Parent. Montréal: Presses de l’Université de Montréal, 2000.

Corcoran, Theresa. Mount Saint Vincent University: A Vision Unfolding, 1873-1988. Lanham, Md.: University Press of America, 1999.

Corcos, Arlette. Montréal, les Juifs et l'école. Montréal: Septentrion, 1997.

Costello, Gladys, ed. Tales told by teachers, 1998: a book of memories. Corner Brook: RTANL (Retired Teachers Association of Newfoundland and Labrador) in cooperation with RB Books, 1998.

Couillard, Marie. “L’influence des États-Unis sur l'élaboration des systèmes d'éducation au Canada au dix-neuvième siècle et sa mise en perspective avec l’Argentine.” Quebec Studies 23 (printemps-été 1997): 82-94.

Coulter, Rebecca Priegert. “'Us Guys in Suits Are Back’: Women, Educational Work and the Market Economy in Canada.” In Education into the Twenty-First Century: Dangerous Terrain for Women?, ed. Alison Mackinnon, Inga Elgqvist-Saltzman, and Alison Prentice. London: Falmer Press, 1998, 107-17.

Couturier, Jacques-Paul. Construire un savoir: L'enseignement supérieur au Madawaska, 1946-1974. Moncton: Les Éditions de l’Acadie, 1999.

Couturier, Jacques-Paul. Répertoire des lois touchant à l'éducation au Nouveau-Brunswick, 1871-1966. Edmundston: PréCLé, 1995. http://www.cuslm.ca/ clio/precle/replois.htm

Couturier, Jacques-Paul, et al. Bibliographie d'histoire de l'éducation au Nouveau-Brunswick: sources imprimées et études. (1995) http://www.cuslm.ca/ clio/precle/biblio.htm

Couturier, Jacques-Paul, Wendy Johnston, and Sylvie LeBel. La question scolaire à Caraquet (1875) vue par les journaux de la province: recueil de documents. (1 Dec. 1995) http://www.cuslm.ca/ clio/precle/cara.htm

Croteau, Georges. Les frères éducateurs, 1920-1965. Ville La Salle: Éditions Hurtubise HMH, 1996. 
Crowley, Terry, and Alexander M. Ross. The College on the Hill: A New History of the Ontario Agricultural College, 1874-1999. Rev. ed. Toronto: Dundurn Press, 1999.

Cuban, Larry. How Scholars Trumped Teachers: Change without Reform in University Curriculum, Teaching and Research, 1890-1990. New York: Teachers College Press, 1999.

Curtis, Bruce. “The State of Tutelage in Lower Canada, 1835-1851.” History of Education Quarterly 37, 1 (1997): 25-43.

Dahlie, Betty. "Jessie Margaret Henderson: Pioneer Teacher of Spirit River." Alberta History 48, 4 (Autumn 2000): 17-24.

Damer, Eric. Discovery by Design: The Department of Mechanical Engineering of the University of British Columbia: Origins and History, 1907-2001. Vancouver: Ronsdale Press, 2001.

Damer, Eric J. "The Rise and Fall of a Science of Adult Education at the University of British Columbia, 1957-1985.” Historical Studies in Education/Revue d'histoire de l'éducation 12, 1/2 (Spring 2000): 29-53.

Danylchuk, K.E. “Academic Performance of Intercollegiate Athletes at a Canadian University: Comparisons by Gender, Type of Sport and Affiliated Faculty.” Avante 1, 2 (1995): 78-93.

Danziger, Edmund J., Jr. "Taking Hold of the Tools: Post-Secondary Education for Canada's Walpole Island First Nation, 1965-1994.” Canadian Journal of Native Studies 16, 2 (1996): 229-46.

Darroch, Gordon. "Home and Away: Patterns of Residence, Schooling and Work among Children and Never Married Young Adults, Canada, 1871 and 1901.” Journal of Family History 26, 2 (April 2001): 220-50.

Davies, Gwendolyn. "Private Education for Women in Early Nova Scotia: 1784-1894.” Atlantis 20, 1 (Fall-Winter 1995): 9-20.

Davies, Scott, Clayton Mosher, and Bill O’Grady. "Educating Women: Gender Inequalities among Canadian University Graduates.” Canadian Review of Sociology and Anthropology 33, 2 (May 1996): 125-42.

Davis, Bob. What Ever Happened to High School History? Toronto: James Lorimer, 1995.

Deblois, Claude, Céline Castonguay, et Lise Corriveau. "La culture de l'école secondaire québécoise: une rétrospective.” Recherches sociographiques 38, 2 (mai-août 1997): 251-77.

Dehli, Kari. "Love and Knowledge: Adult Education in the Toronto Home and School Council, 1916-40.” Ontario History 88, 3 (Sept. 1996): 207-28. 
Deiter, Constance. From Our Mother's Arms: The Intergenerational Impact of Residential Schools in Saskatchewan. Toronto: United Church Publishing, 1998.

Den Boggende, Bert. “'Alone in the Province’: The Cobourg Ladies’ Seminary-Burlington Ladies’ Academy, 1842-1851.” Ontario History 89, 1 (Mar. 1997): 53-74.

Den Boggende, Bert. “Dutch Calvinists and Ontario’s Christian School Movement: The Hamilton Christian School before 1960.” Ontario History 91, 1 (1999): 39-62.

Den Boggende, Bert. “The Female Department of Cobourg’s Upper Canada Academy, 1836-42: 'A Monument of Wisdom, Piety, Loyalty and Patriotism,’” Ontario History 87, 3 (Sept. 1995): 271-91.

Denney, Charles D. “Hot Heads and Cold Feet.” Alberta History 48, 2 (Spring 2000): 26-27. (School furnaces)

Dennison, John D. Challenge and Opportunity: Canada's Community Colleges at the Crossroads. Vancouver: University of British Columbia Press, 1995.

Des Roches, Marc. 150 ans au service des Québécois: histoire de la Commission des écoles catholiques de Québec: 1846-1996. [Québec]: La Commission des écoles catholiques de Québec, 1995.

Desbiens, Josée. Le Collège Regina Assumpta, 1955-1995: 40 ans d'éducation au féminin. [Saint-Laurent, Québec]: Fides, 1995.

Deshaies, Laurent. “L’apprentissage de la géographie au Québec selon les manuels de pédagogie (1850-1983).” Cahiers de géographie du Québec 43, 120 (1999): 585-604.

Deslandes, Rollande, Nadia Rousseau, et Nicole Royer. “Collaboration écolefamille-communauté: Étude sur la perception des connaissances et le sentiment de compétence des etudiants inscrits en formation initiale en enseignement.” Journal of Educational Thought 36, 1 (Apr. 2002): 27-52.

Dewar, Katherine, and Wayne Wright. This caring place: the history of Prince County Hospital and School of Nursing. Summerside: Prince County Hospital Foundation, 2001.

Djwa, Sandra. Professing English at UBC: The Legacy of Roy Daniells and Garnett Sedgewick: The 1999 Garnett Sedgewick Memorial Lecture. Sedgewick Memorial Lecture. Vancouver: Ronsdale Press, 1999.

Dodd, Dianne. "Helen MacMurchy, MD: Gender and Professional Conflict in the Medical Inspection of Toronto Schools, 1910-1911.” Ontario History 93, 2 (2001): 127-49. 
Donaldson, Laura E. "Writing the talking stick: alphabetic literacy as colonial technology and postcolonial appropriation.” American Indian Quarterly 22, 1-2 (1998): 46-62.

Dorsey, Peter A. "Going to School with Savages: Authorship and Authority Among the Jesuits of New France." William and Mary Quarterly 55, 3 (1998): 399-420.

Doucet, Azarias. "Les inspecteurs d'écoles francophones du NouveauBrunswick 1886-1967.” La revue d'histoire de la Société historique Nicolas-Denys 29, 1 (janv.-avr. 2001): 29-32.

Down, Edith, and Sisters of Saint Anne. A Century of Service, 1858-1958: A History of the Sisters of Saint Ann and Their Contribution to Education in British Columbia, the Yukon and Alaska. $2^{\text {nd }}$ ed. Victoria: Sisters of Saint Ann, 1999.

Doyon, Nova. "L’Académie de Montréal (1778): Fiction littéraire ou projet utopique?” MENS: Revue d'histoire intellectuelle de l'Amérique française I, 2, (2001): 115-40.

Dufour, Andrée. Histoire de l'éducation au Québec. Montréal: Boréal, 1997.

Dufour, Andrée. "Les institutrices rurales du Bas-Canada: incompétentes et inexpérimentées?” Revue d'histoire de l'Amérique française 51, 4 (1998): 521-48.

Dufour, Andrée. Tous à l'école: État, communautés rurales et scolarisation au Québec de 1826 à 1859. Ville La Salle: Éditions Hurtubise HMH, 1996.

Dunae, Patrick. "School Records and Education Anniversaries." British Columbia Historical News 35, 1 (2001/2002): 23. (150 anniversary of B.C. school system in 2002)

Duval, Roch. Les cheminements éducatifs de l'orientation et de la pédagogie de 1943 à 1993 à la Faculté des sciences de l'éducation de l'Université Laval. Sainte-Foy, Québec: Université Laval, 1995.

Edwards, Reginald. "1854 Revisited: McGill College Seeks a New Principal.” McGill Journal of Education 33, 2 (1998): 127-76.

Elshorbagy, Amin, and Dieter J. Schönwetter. "Engineer Morphing: Bridging the Gap Between Classroom Teaching and the Engineering Profession." The International Journal of Engineering Education 18, 3 (2002): 295300.

Errington, Elizabeth Jane. Wives and Mothers, School Mistresses and Scullery Maids: Working Women in Upper Canada, 1790-1840. Montreal and Kingston: McGill-Queen's University Press, 1995. 
Evans, Doris, and Gertrude Tynes. Telling the Truth: Reflections: Segregated Schools in Nova Scotia. Hantsport, NS: Lancelot Press, 1995.

Ewen, Geoffrey. "Montreal Catholic School Teachers, International Unions, and Archbishop Bruchési: The Association de bien-être des instituteurs et institutrices de Montréal, 1919-20.” Historical Studies in Education/Revue d'histoire de l'éducation 12, 1/2 (Spring 2000): 54-72.

Ewing, Chalen. Childhood Lost: The Residential School Experience. Saskatoon: Saskatchewan Indian Cultural Centre, 2001.

Faessler, Gary. “Kelowna Secondary School.” Award 15, 6 (2001): 29.

Farley, John. "Building a school of nursing with Rockefeller money: three Nova Scotians at the University of Toronto." Journal of the Royal Nova Scotia Historical Society 3 (2000): 85-104.

Faulkner, Tom. "The religious roots of the universities in the Atlantic provinces.” In Religious studies in Atlantic Canada: a state-of-the-art review, ed. W.R. Paul. Waterloo: Wilfrid Laurier University Press, 2001, 17-25.

Fay, Terence J. “A Historiography of Recent Publications on Catholic Native Residential Schools.” Canadian Catholic Historical Association Historical Studies 61 (1995): 79-98.

Fecteau, Jean-Marie, et al. “Une politique de l’enfance délinquante et en danger: la mise en place des écoles de reforme et d'industrie au Québec 1840 - 1873.” Crime, Histoire \& Sociétés 2, 1 (1998): 75-110.

Field, John. "Educational Studies Beyond School.” British Journal of Educational Studies 50, 1 (March 2002): 120-43.

Fielding, John. "Tales from the Crypt or Writing the Ontario, Canadian and World Studies Curriculum.” Our Schools/Ourselves 11, 3 (Spring 2002): 77-84.

Fisher, Donald, Kjell Rubenson, and Gerry Della Mattia. Prospects for a Provincial Design of the British Columbia Post-Secondary Education System. Vancouver: Centre for Policy Studies in Higher Education and Training, University of British Columbia, 2001.

Fitzgerald, John Edward. “Archbishop E.P. Roche, J.R. Smallwood, and Denominational Rights in Newfoundland Education, 1948.” Canadian Catholic Historical Association Historical Studies 65 (1999): 28-49.

Fleming, Thomas, ed. School Leadership: Essays on the British Columbia Experience, 1872-1995. Mill Bay: Bendall Books, 2001.

Fleming, Thomas and Carolyn Smyly. "The Diary of Mary Williams: A Cameo of Rural Schooling in British Columbia, 1922-1924.” In Children, Teachers, and Schools in the History of British Columbia, ed. 
Jean Barman, Neil Sutherland, and J. Donald Wilson. Calgary: Detselig Enterprises, 1995, 259-84.

Fleming, Thomas, and David Conway. "Setting Standards in the West: C.B. Conway, Science, and School Reform in British Columbia, 1938-1974.” Canadian Journal of Education 21, 3 (1996): 294-317.

Fletcher, Garry. "Racerocks.com: Education and Research in Real Time.” Education Canada 41, 3 (2001): 24-27.

Forbes, E.R. "Dalhousie University and the Flowering of Atlantic Provinces Historiography, 1960-1980.” Acadiensis 30, 1 (2000): 45-69.

Fox, Michael. "The Geographic Implications of School Board Reform in Quebec.” Canadian Geographic 40, 1 (Spring 1996): 54-68.

Fraser, Brian J. Church, College, and Clergy: A History of Theological Education at Knox College, Toronto, 1844-1994. Montreal: McGillQueen’s University Press, 1995.

Frenette, Normand, et Saeed Quazi. "L'effectif et la rétention des élèves dans les écoles françaises en situation minoritaire au Canada, 1980-1994.” Canadian and International Education 26, 2 (Dec. 1997): 28-41.

Friesen, Gerald, and Lucy Taksa. "Workers’ Education in Australia and Canada: A Comparative Approach to Labour's Cultural History.” Labour/Le Travail 38 (Fall 1996): 170-97.

Friesen, John W. "The Function of Legends as a Teaching Tool in PreColonial First Nations’ Societies.” Interchange 30, 3 (Jan. 1999): 305-22.

Frost, Stanley Brice. James McGill of Montreal. Montreal and Kingston: McGill-Queen's University Press, 1995.

Furniss, Elizabeth. Victims of Benevolence: The Dark Legacy of the Williams Lake Residential School. Rev. ed. Vancouver: Arsenal Pulp Press, 1995.

Gagnon, Robert. Histoire de la Commission des écoles catholiques de Montréal. Montréal: Boréal, 1996.

Gagnon, Robert. Histoire de l’École Le Plateau, 1856-1996. Montréal: Commission des écoles catholiques de Montréal, 1997.

Gagnon, Robert et Jean-Francois Auger. “L’invention en milieu universitaire: les recherches sur la télévision à Polytechnique dans les années 1930.” Scientia Canadensis 19, 48 (1995): 51-75.

Galarneau, Claude. “L’enseignement médical à Québec (1800-1848).” Les Cahiers des Dix 53 (1999): 37-64.

Gallichan, Gilles, dir. Les bibliothèques québécoises d'hier à aujourd'hui. Montréal: Éditions ASTED, 1998. 
Gardner, Paul L. and Ann Marie Hill. "Technology Education in Ontario: Evolution, Achievements, Critiques, and Challenges. Part 1: The Context.” International Journal of Technology and Design Education 9, 2 (Jan. 1999): 103-36.

Gaudet, Jeanne d'Arc, et Claire Lapointe. "Les Acadiennes du NouveauBrunswick et l'éducation: un bilan de la décennie 1986-1996.” Dans L'Acadie au féminin: un regard multidisciplinaire sur les Acadiennes et les Cadiennes. Sous la direction de Maurice Basque et al. (Moncton: Université de Moncton, 2000): 15-44.

Gauthier, Angela, Nick Kach, and Kas Mazurek. "The Ruthenian School Revolt of 1913: Linguistic and Cultural Conflict in Alberta." Historical Studies in Education/Revue d'histoire de l'éducation 8, 2 (1996): 199210.

Gayle, Vernon, Damon Berridge, and Richard Davis. "Young People’s Entry into Higher Education: quantifying influential factors." Oxford Review of Education 28, 1 (March 2002): 5-20.

Gelman, Susan. "Stratford (Normal School) Teachers’ College, 1908-1973.” Historical Studies in Education 14, 1 (Spring 2002): 113-20.

Gidney, Catherine. "Poisoning the Student Mind?: The Student Christian Movement at the University of Toronto, 1920-1965.” Journal of the Canadian Historical Association/Revue de la société historique du Canada 8 (1997): 147-64.

Gidney, Catherine. "Under the President’s Gaze: Sexuality and Morality at a Canadian University during the Second World War." Canadian Historical Review 82, 1 (Mar. 2001): 36-54.

Gidney, R.D. From Hope to Harris: The Reshaping of Ontario's Schools. Toronto: University of Toronto Press, 1999.

Gidney, R.D., and W.P.J. Millar. "The Christian Recessional in Ontario's Public Schools.” In Religion and Public Life in Canada: Historical and Comparative Perspectives, ed. Marguerite Van Die. Toronto: University of Toronto Press, 2001, 275-93.

Gidney, R.D., and W.P.J. Millar. "Medical Students at the University of Toronto, 1910-1940: A Profile.” Canadian Bulletin of Medical History 13, 1 (1996): 29-52.

Gidney, R.D., and W.P.J. Millar. "Quantity and Quality: The Problem of Admissions in Medicine at the University of Toronto, 1910-51."

Historical Studies in Education/Revue d'histoire de l'éducation 9, 2 (1997): 165-89.

Gidney, R.D., and W.P.J. Millar. "Starting With the Task: Rethinking the History of Nineteenth-Century Professional Education." Historical Studies in Education/Revue d'histoire de l'éducation 8, 2 (1996): 167-81. 
Gillett, Margaret, and Ann Beer, eds. Our Own Agendas: Autobiographical Essays by Women Associated with McGill University. Montreal and Kingston: McGill-Queen's University Press, 1995.

Gillie, Bernard C. "When It Was Easy to Go Teaching.” British Columbia Historical News 29, 2 (1996): 19-22.

Gleason, Mona. "Disciplining the Student Body: Schooling and the Construction of Canadian Children's Bodies, 1930-1960.” History of Education Quarterly 41, 2 (summer 2001): 189-215.

Gleason, Mona. "Embodied Negotiations: Children's Bodies and Historical Change in Canada, 1930-1960.” Journal of Canadian Studies 34, 1 (1999): 112-38.

Gleason, Mona. "The History of Psychology and the History of Education: What Can Interdisciplinary Research Offer?” Historical Studies in Education/Revue d'histoire de l'éducation 9, 1 (1997): 98-106.

Gleason, Mona. Normalizing the Ideal: Psychology, Schooling, and the Family in Postwar Canada. Toronto: University of Toronto Press, 1999.

Gleason, Mona. "Psychology and the Construction of the 'Normal' Family in Postwar Canada, 1945-60.” Canadian Historical Review 78, 3 (Sept. 1997): 442-77.

Gleason, Mona. "Race, Class, and Health: School Medical Inspection and 'Healthy' Children in British Columbia, 1890-1930.” Canadian Bulletin of Medical History 19, 1 (2002): 95-112.

Glegg, Alastair. "Schools in the City: The Effects of Increasing Urbanisation on Education in Victoria, British Columbia, 1920-1929.” Journal of Educational Administration and History 33, 2 (July 2001): 73-86.

Godwin, C.D. "Government Policy and the Provision of Teachers.” British Journal of Educational Studies 50, 1 (Mar. 2002): 76-99.

Gorman, Eunice. “Early Glenrose School Days.” In Okanagan History, 60 ${ }^{\text {th }}$ Annual Report, 1996, 158-60.

Gough, Ruby L. "Robert Edwards Holloway: Science and Science Education in St. John's, Newfoundland, 1874-1904." Newfoundland Studies 2, 2 (Fall 1995): 223-49.

Goulet, Henri. Histoire du syndicat des chargé-e-s de cours de l'Université de Montréal, 1978-1998. Montréal: RCHTQ, coll. "Études et documents" no. 10, 1998.

Grace, Andre P. "Canadian and US Adult Learning (1945-1970) and the Culture, Politics and Place of Lifelong Learning.” International Journal of Lifelong Education, 19, 2 (Mar./Apr. 2000): 141-58. 
Graham, Amanda. "Not a Perfect Solution but a Good Illustration: The Life and Times of The University of Canada North, 1970-1985.” Northern Review 12/13 (Summer 1994/Winter 1994): 117-34.

Graham, Elizabeth, comp. The Mush Hole: Life at Two Indian Residential Schools. Waterloo, Ont.: Heffle Publishers, 1997.

Graham, Hugh. Recollections of a Catholic Education. Kingston: Quarry Press, 1997.

Grant, Agnes. No End of Grief: Indian Residential Schools in Canada. Winnipeg: Pemmican Publications, 1996.

Gray, Susan. "Methodist Indian Day Schools and Indian Communities in Northern Manitoba, 1890-1925.” Manitoba History 30 (Autumn 1995): 2-16.

Greffard, Madeleine. Portes ouvertes à l'École de la rue. Montréal: Boréal, 2001.

Groulx, L-H. “De la vocation féminine à l'expertise féministe: essai sur l'évolution du service social au Québec (1939-1990).” Revue d'histoire de l'Amérique française 49, 3 (hiver 1996): 357-94.

Gresko, Jacqueline. “The 'Serfs of the System'? Oblate Brothers and the Sisters of Saint Ann in British Columbia Schools, 1858-1920.” In Western Oblate Studies/Études oblates de l'Ouest, ed. Raymond Huel. No. 4. Edmonton: Western Canadian Publishers, 1996, 119-42.

Guenther, B.L. “'Monuments to God’s Faithfulness': Mennonite Brethren Bible Schools in Western Canada, 1913-1960.” Direction 30, 1 (2001): 21-32.

Guentzel, Ralph P. “The Centrale de l’Enseignement du Québec and Quebec Separatist Nationalism, 1960-80.” Canadian Historical Review 80, 1 (Mar. 1999): 61-82.

Haig-Brown, Celia, et al. Making the Spirit Dance Within: Native Students and the Joe Dugllette High School. Toronto: James Lorimer, 1997.

Hallman, Dianne M. “Agnes Maule Machar on the Higher Education of Women." Historical Studies in Education/Revue d'histoire de l'éducation 13, 2 (2001): 165-82.

Hallman, Dianne M. “Telling Tales Out of School: Twentieth-Century Women Teachers in Saskatchewan.” Saskatchewan History 49, 2 (Fall 1997): 3-17.

Hamel, Thérèse. “La production pédagogique des Sœurs de la Congrégation de Notre-Dame: 1858-1991.” Études d'histoire religieuse 65 (1999): 6788. 
Hamel, Thérèse. Un siècle de formation des maîtres au Québec, 1836-1939. Montréal: Hurtubise/HMH, 1995.

Hamel, Thérèse, and Marie-Josée Larocque. "Observations from Quebec: the emergence of a research culture in education through legitimacy and universitarisation, 1940-2000.” European Educational Research Journal $<$ http://www.triangle.co.uk/EERJ> 1, 1 (2002): 99-117.

Hamel, Thérèse, Michel Morisset, et Jacques Tondreau. "Les agriculteurs à l'école: les savoirs enseignés dans les écoles moyennes et régionales au Québec, 1926-69.” Canadian Journal of Education 24, 4 (1999): 398410.

Hamelin, Christine. "A Sense of Purpose: Ottawa Students and the Second World War.” Canadian Military History 6, 1 (Spring 1997): 34-41.

Hamelin, Jean. Histoire de l'Université Laval: les péripéties d'une idée. Québec: Les Presses de l’Université Laval, 1995.

Hamelin, Pierre. "Le développement de l'alphabétisation sur la Côte-du-Sud, 1680-1869." Dans L'histoire de la culture et de l'imprimé: hommages à Claude Galarneau, dir. Yvan Lamonde et Gilles Gallichan. Sainte-Foy: Presses de l’Université Laval, 1996, 123-36.

Hampton, Eber. “Towards a Redefinition of Indian Education.” In First Nations Education in Canada: The Circle Unfolds, ed. Jean Barman and Marie Battiste. Vancouver: University of British Columbia, 1995, 5-46.

Hanaway, Joseph, and Richard Cruess. McGill Medicine, Volume 1: The First Half Century, 1829-1885. Montreal and Kingston: McGill-Queen's University Press, 1996.

Hardy, Cynthia. The Politics of Collegiality: Retrenchment Strategies in Canadian Universities. Montréal: McGill-Queen’s University Press, 1996.

Harrigan, Patrick J. "The Controversy about Athletic Scholarships in Canadian Universities: A Historical Perspective.” Sport History Review 32, 2 (2001): 140-68.

Harris, Carol E. A Sense of Themselves: Elizabeth Murray's Leadership in School and Community. Halifax: Fernwood, 1998.

Harrison, Joshua C. "On Scope and Assessment in Modern Engineering Education.” The International Journal of Engineering Education 18, 3 (2002): 301-6.

Harrison, Trevor W., and Jerrold L. Kachur, eds. Contested Classrooms: Education, Globalization, and Democracy in Alberta. Edmonton: University of Alberta Press and Parkland Institute, 1999. 
Haverluck, Tim, ed. School Days: Manitobans Tell Their Personal Stories of Schools They Attended Here and Around the World. Winnipeg: Hugh John Macdonald Junior High School Challenge Program, 1994.

Hayday Matthew. "Confusing and Conflicting Agendas: Federalism, Official Languages and the Development of the Bilingualism in Education Program in Ontario, 1970-1983.” Journal of Canadian Studies 36, 1 (Spring 2001): 50-79.

Hayes, Wilma. "Hall of Learning - Oyama’s One-Room High School.” In Okanagan History, 60 ${ }^{\text {th }}$ Annual Report, 1996, 155-57.

Healy, Esther. St. Francis College: The Legacy of a Classical College, 18541898. [Melbourne, Québec]: Richmond County Historical Society, 1995.

Heap, Ruby. "From the Science of Housekeeping to the Science of Nutrition: Pioneers in Canadian Nutrition and Dietetics at the University of Toronto’s Faculty of Household Science, 1900-1950.” In Challenging Professions: Historical and Contemporary Perspectives on Women's Professional Work, ed. Elizabeth Smyth, Sandra Acker, Paula Bourne, and Alison Prentice. Toronto: University of Toronto Press, 1999, 141-70.

Heap, Ruby. “Training Women for a New 'Woman’s Profession': Physiotherapy Education at the University of Toronto, 1917-1980.” History of Education Quarterly 35, 2 (1995): 135-58.

Heaps, D.A. “Diary of a European Tour, 1900: Margaret Addison’s Sentimental Journey and Education.” Canadian Woman Studies 21, 2 (2001): 140-41.

Heath, G. Louis. Leaves of Maple: An Illinois State University Professor's Memoirs of Seven Summers Teaching in Canadian Universities, 19721978. [Bloomington, Ind.]: $1^{\text {st }}$ Books Library [2001].

Heathorn, Stephen. For Home, Country and Race: Constructing Gender, Class, and Englishness in the Elementary School, 1880-1914. Toronto: University of Toronto Press, 2000.

Hesch, Rick. "Teacher Education and Aboriginal Opposition.” In First Nations Education in Canada: The Circle Unfolds, ed. Jean Barman and Marie Battiste. Vancouver: University of British Columbia Press, 1995, 179-207.

Hewitt, S.R. “Spying 101: The RCMP's Secret Activities at the University of Saskatchewan, 1920-1971.” Saskatchewan History 47, 2 (Fall 1995): 2031.

Hewitt, Steve. “'Information Believed True’: RCMP Security Intelligence Activities on Canadian University Campuses and the Controversy Surrounding Them, 1961-71.” Canadian Historical Review 81, 2 (2000): $191-228$. 
Hidas, Peter I. "The Hungarian Refugee Student Movement of 1956-57 and Canada.” Canadian Ethnic Studies 30, 1 (1998): 19-49.

Hobbins, Alan J. “'Dear Rufus': a law student’s life at McGill in the roaring twenties, from the letters of John P. Humphrey." McGill Law Journal 44, 3 (1999): 753-78.

Hodysh, Henry. "Towards a History of Educational Research in Canada: Content Analysis of the AJER." Historical Studies in Education/Revue d'histoire de l'éducation, 12, 1/2 (Spring 2000): 163-68.

Hodysh, Henry W. "Source Criticism in Educational Research,” Education Society 16, 2 (1998).

Hollihan, K.A. “'Making us do the things we ought to do': Constructing Teacher Identity in Alberta Normal Schools." Journal of Historical Sociology 13, 2 (2000): 172-89.

Hollihan, K.A. “'Willing to Listen Humbly’: Practice Teaching in Alberta Normal Schools, 1906-44.” Historical Studies in Education/Revue d'histoire de l'éducation 9, 2 (1997): 237-50.

Hood, David. "Some Fiscal Realities of School Reform in Victorian Halifax." Nova Scotia Historical Review 16, 1 (1996): 61-80.

Horn, Michiel. Academic Freedom in Canada: A History. Toronto: University of Toronto Press, 1999.

Horn, Michiel. "Canadian Universities, Academic Freedom, Labour, and the Left.” Labour/Le Travail 46 (Fall 2000): 439-68.

Horn, Michiel. "Socialism and academic freedom at McGill." University Affairs 40, 9 (1999): 24-27.

Horn, Michiel. "Students and Academic Freedom.” Historical Studies in Education/Revue d'histoire de l'éducation 11, 1 (1999): 1-32.

Hull, J.P. "Strictly by the book: text books and the control of production in the North American pulp and paper industry." History of Education 27, 1 (1998): 85-96.

Hull, James. "Federal Science and Education for Industry at McGill, 191338." Historical Studies in Education/Revue d'histoire de l'éducation 13, 1 (Spring 2001): 1-17.

Hulse, Elizabeth, ed. Thinking with Both Hands: Sir Daniel Wilson in the Old World and the New. Toronto: University of Toronto Press, 1999.

Humphries, Reginald. "Salmon Arm Elementary School 1989-1998.” Okanagan History 62 (1998): 57-66. 
Jack, Agnes S., ed. Behind Closed Doors: Stories From the Kamloops Residential School. Penticton: Theytus Books, 2001.

James, Cathy L. “'Not Merely for the Sake of an Evening’s Entertainment': The Educational Uses of Theatre in Toronto's Settlement Houses, 19101930.” History of Education Quarterly 38, 3 (1998): 287-311.

James, Cathy L. "Practical Diversions and Educational Amusements: Evangelia House and the Advent of Canada's Settlement Movement, 1902-09.” Historical Studies in Education/Revue d'histoire de l'éducation 10, 1/2 (1998): 48-66.

James, Cathy. “Reforming Reform: Toronto’s Settlement House Movement, 1900-20.” Canadian Historical Review 82, 1 (Mar. 2001): 55-90.

Jeffery, Bonnie, and Emily Drzymala. "Prairie Social Work Education: Models of a Delivery in Saskatchewan and Alberta.” Prairie Forum 27, 1 (Spring 2002): 147-60.

Jensen, Devon. “A Theoretical Model for Examining the Link between Governance and Philosophy in Higher Education.” Interchange 32, 4 (2001): 395-417.

Joannette, Nelson K. “The Benefits of Education: Teachers' Pensions in Nineteenth and Early Twentieth-Century Ontario.” Ontario History 87, 2 (June 1995): 193-207.

Joblin, Kingslay. A Life in Vic: 70 Years of Victoria University, 1929-1999. Toronto: Childe Thursday, 2000.

Johansson, Ulla. "In Praise of Talent: Meritocracy and Social Justice in the Discourses of Grammar School Teachers: The Case of Sweden, 19271960.” Historical Studies in Education 14, 1 (Spring 2002): 93-112.

Johnston, Wendy. "Aux sources du développement inégal: le financement de l'enseignement public à Montréal de 1920 à 1945,” Canadian Historical Review 76, 1 (Mar. 1995), 43-80.

Johnston, Wendy. "Contestation et continuité: les comités confessionnels et la gestion des écoles publiques au Québec (1920-1945).” Revue d'histoire de l'Amérique française 48, 3 (hiver 1995): 403-34.

Jones, Glen A., ed. Higher Education in Canada: Different Systems, Different Perspectives. New York: Garland Publishing, 1997.

Jones, Ken. A History of Summerland Schools. Summerland, BC: Valley Pub, 1999.

Joyal, Renée. “L’Acte concernant les écoles d’industrie (1869): une mesure de prophylaxie sociale dans un Québec en voie d'urbanisation.” Revue d'histoire de l'Amérique française 50, 2 (automne 1996): 227-40. 
Julien, Richard. "The Legal Recognition of All-French Schools in Saskatchewan: A Long and Often Difficult Odyssey.” Canadian Ethnic Studies 27, 2 (1995): 101-44.

Juteau, Danielle, et Nicole Laurin. Un métier et une vocation: le travail des religieuses au Québec de 1901 à 1971. Montréal: Presses de l'Université de Montréal, 1997.

Keller, J.A. "Stature Analysis of Perris Indian School Students, 1894-99." Canadian Bulletin of Medical History 18, 1 (2001): 109-40.

Kelm, Mary Ellen. “'A Scandalous Procession’: Residential Schooling and the Re/formation of Aboriginal Bodies, 1900-1950.” Native Studies Review 11, 2 (1996): 51-88.

Kent, Peter. “The Unrealized Potential of Canada's Universities.” Acadiensis 31, 2 (Spring 2002): 207-14.

Kent, Roxanne Feldman. Educating Vancouver's Jewish Children, The Vancouver Talmud Torah 1913-1959 and Beyond. Vancouver: The Author, 1995.

Kidd, J.R. Roby Kidd, Adult Educator, 1915-1982: The Autobiography of an Adult Education. Toronto: OISE Press, 1995.

Kim, Ki Su. "J.R. Smallwood and the Negotiation of a School System for Newfoundland, 1946-48.” Newfoundland Studies 11, 1 (1995): 53-74.

Kindling the Spark: The Era of One-Room Schools, An Anthology of Teachers' Experiences. Vancouver: British Columbia Retired Teachers' Association, 1996.

King, Alyson E. “Centres of 'Home-Like Influence': Residences for Women at the University of Toronto." Material History Review/Revue d'histoire de la culture matérielle 49 (Spring 1999): 39-59.

King, Alyson E. Women and the Professions: A Bibliography. Toronto: Centre for Women's Studies in Education, OISE/University of Toronto, 1999.

Kirk, David. Schooling Beyond Borders: School Practice and Public Discourse 1880-1950. 1998.

Knight, Claudette. "Black Parents Speak: Education in Mid-NineteenthCentury Canada West.” Ontario History 89, 4 (1997): 269-84.

Knockwood, Isabelle. Out of the Depths: The Experiences of Mi'kmaw Children at the Indian Residential School at Shubenacadie, Nova Scotia. Rev. ed. Lockeport: Roseway Publishing, 2000.

Kops, William J. "The Tweedie Years, 1949-1975: Continuing Education Division, University of Manitoba." Canadian Journal of University Continuing Education 22, 1 (Spring 1996): 21-32. 
Krotz, Larry, Erica Martin, and Philip Fernandez, comps. Frontier College Letters: One Hundred Years of Teaching, Learning \& National Building. Toronto: Frontier College Frontière, 1999.

Kuehn, Larry. "'Nobody Voted for That': The Attack on Public Education in B.C.” Our Schools/Ourselves 11, 3 (Spring 2002): 51-62.

Laberge, Paul-André. Histoire de la Faculté des sciences de l'administration de l'Université Laval, 1924-1965: l'épopée des Frères des écoles chrétiennes. Québec: Université Laval, Faculté des sciences de l'administration, 1999.

Lachapelle, Huguette. “L'enseignement du français au Québec, 25 ans d'histoire et de passion.” Québec français 100 (hiver 1996): 15-19.

Lambert, Barbara Ann. Chalkdust and Outhouses: West Coast Schools, 18931950. Powell River, BC: Barbara Ann Lambert, 2000.

Lambert, Garth. Dethroning Classics and Inventing English: Liberal Education and Culture in Nineteenth-Century Ontario. Toronto: Our Schools/Our Selves, 1995.

Lampron, Réal. Un éducateur de classe: un religieux de taille: Armand Tassé, frère Albert-Marie. Saint-Romuald: Juvénat Notre-Dame-duSaint-Laurent, 2000.

Landry, Élisa. “La confessionnalité scolaire au Québec: Des jalons historiques.” L’Église canadienne 32, 9 (septembre 1999): 294-97.

Lanning, Robert. “Awakening a Demand for Schooling: Educational Inspection's Impact on Rural Nova Scotia, 1855-74.” Historical Studies in Education/Revue d'histoire de l'éducation 12, 1/2 (Spring 2000): 12942.

Lapointe, Richard. "Mixité confessionnelle et enseignement religieux dans les écoles publiques du Québec (1840-1950): les pressions d'une cohabitation.” Dans Enseigner le catéchisme: autorités et institutions, $X V I e-X X e$ siècles, dir. Raymond Brodeur et Brigitte Caulier. Québec/Paris: Presses de l’Université Laval/Éditions du Cerf, 1997, 285302.

Lascelles, Thomas A. "Indian Residential Schools — The Historical Perspective.” Mission: Journal of Mission Studies 2, 2 (1995): 181-92.

Latham, Jackie. "Pestalozzi and James Pierrepont Greaves: a shared education philosophy.” History of Education 31, 1 (Jan. 2002): 59-70.

Lathrop, Anna H. "Portrait of a Physical': A Case Study of Elizabeth Pitt Barron (1904-98).” Historical Studies in Education/Revue d'histoire de l'éducation 11, 2 (1999): 131-69. 
Lathrop, Anna H. “' 'Strap an Axe to Your Belt’: Camp Counsellor Training and the Socialization of Women at the Margaret Eaton School (19251941).” Sport History Review 32, 2 (2001): 110-25.

Lawn, Martin. "The Puzzle of the Public: (Re) Constructing the Teacher in the Public Service.” Historical Studies in Education/Revue d'histoire de l'éducation 9, 1 (Spring/printemps 1997): 107-15.

Layman, Grace M. From Then On. St. John’s: H. Cuff, 1997. (Autobiography of a teacher)

Leach, James. “Academic Militarism: The Canadian Officers’ Training Corps at the University of Toronto During the First World War." Ontario Journal of Higher Education (1995): 107-24.

Leavitt, Robert. "Language and Culture Content in Native Education.” In First Nations Education in Canada: The Circle Unfolds, ed. Jean Barman and Marie Battiste. Vancouver: University of British Columbia Press, 1995, 123-38.

LeGrow, Kathy. "End to the Rocky Road for Education in New Brunswick?” Education Today 12, 3 (Fall 2000): 16-17.

Lei, Christine. "Material Culture at the Loretto School for Girls in Hamilton, 1861-1971.” Canadian Catholic Historical Association Historical Studies 66 (2000): 92-113.

Lemerise, Suzanne, et Leah Sherman. "La place du dessin dans les politiques scolaires catholiques et protestants du Québec.” Historical Studies in Education/Revue d'histoire de l'éducation 8, 1 (1996): 1-14.

Lemieux, Thomas, and David Card. "Education, Earnings, and the 'Canadian G.I. Bill.”’ Canadian Journal of Economics/Revue canadienne d'économique 34, 2 (2001): 313-44.

Lessard, Claude, et Maurice Tardif. La profession enseignante au Québec, 1945-1990: Histoire, structures, systeme. Montréal: Presses de l’Université de Montréal, 1996.

LeVasseur, Louis. “L’enseignement dans les collèges classiques au XXe siècle: une vision du monde en difficile harmonie avec la modernisation de la société québécoise.” Historical Studies in Education 14, 1 (Spring 2002): 35-66.

Levi, Charles. “Phyllis Grierson, Margaret Ross, and the Queen’s Hall Girls: Intergroup Conflict Among University College Women 1910-21.”

Historical Studies in Education/Revue d'histoire de l'éducation 12, 1/2 (Spring 2000): 73-92.

Levi, Charles. "Student Administration and Administrative Careers 1921-59." Historical Studies in Education/Revue d'histoire de l'éducation 11, 1 (1999): 96-102. 
Levi, Charles. "Student Opinion in Depression and War: The Case of Paul McGillicuddy (1918-42).” Ontario History 87, 4 (Dec. 1995): 345-67.

Lewis, Norah. I Want to Join Your Club: Letters from Rural Children, 1900 1920. Waterloo: Wilfrid Laurier University Press, 1996.

Lewis, Norah, comp. "Letters to the Women's Pages as Primary Source." Historical Studies in Education/Revue d'histoire de l'éducation 9, 1 (1997): 83-97.

Linke, Rob. "Province without school boards: New Brunswick’s experience.” Education Today 11, 1 (1998): 11.

Little, J.I. “'Labouring in a Great Cause': Marcus Child as Pioneer School Inspector in Lower Canada's Eastern Townships, 1852-59.” Historical Studies in Education/Revue d'histoire de l'éducation 10, 1/2 (1998): 85115.

Little, J.I. "School Reform and Community Control in the 1840s: A Case Study from the Eastern Townships." Historical Studies in Education/Revue d'histoire de l'éducation 9, 2 (1997): 153-64.

Low, Brian. "'Lessons in Living': Propaganda and Progressive Education in Rural British Columbia, 1944.” In Beyond the City Limits: Rural History in British Columbia , ed. R.W. Sandwell. Vancouver: UBC Press, 1999.

Lubek, Ian, et al. "Faculty Genealogies in Five Canadian Universities: Historiographical and Pedagogical Concerns." Journal of the History of the Behavioral Sciences 31, 1 (1995): 52-72.

MacBeath, Marie E., and Wendy J. Robbins. See Jane Soar: A Study of Undergraduate Women's Academic Achievement, University of New Brunswick, Fredericton Campus, 1980-90. [Fredericton]: University of New Brunswick, 1992.

MacDougall, Margaret J. The Evolution of Business Education in New Brunswick, 1784-1984. Saint John: ImPresses, 2001.

MacIvor, Madeleine. "Redefining Science Education for Aboriginal Students." In First Nations Education in Canada: The Circle Unfolds, ed. Jean Barman and Marie Battiste. Vancouver: University of British Columbia Press, 1995, 73-98.

Mackay, Ron and Lawence Myles. "A Major Challenge for the Education System: Aboriginal Retention and Dropout.” In First Nations Education in Canada: The Circle Unfolds, ed. Jean Barman and Marie Battiste. Vancouver: University of British Columbia Press, 1995, 157-78.

MacKenzie, A.A. "The History of St. Francis Xavier University.” Acadiensis 28, 1 (Autumn 1998): 127-31. (Review essay) 
MacLeod, Malcolm. "Saint and Survivor: The Presidents of Memorial University College, Part 1.” Newfoundland Quarterly 90, 2 (Spring 1996): 25-31.

MacLeod, Malcolm. "Saint and Survivor: The Presidents of Memorial University College, Part 2.” Newfoundland Quarterly 90, 3 (Summer-Fall 1996): 25-30.

Magnusson, Jamie-Lynn. "Examining Higher Education and Citizenship in a Global Context of Neoliberal Restructuring." Canadian Ethnic Studies/Études Ethniques au Canada 32, 1 (2000): 72-88.

Mahé, Yvette T.M. "Bilingual School District Trustees and Cultural Transmission: The Alberta Experience, 1892-1939.” Historical Studies in Education/Revue d'histoire de l'éducation 9, 1 (1997): 65-82.

Mahé, Yvette T.M. “Bilingual School Teachers’ Cultural Mission and Practices in Alberta before 1940.” Journal of Educational Thought 34, 2 (Aug. 2000): 135-64.

Mahé, Yvette T.M. "Official and Unofficial School Inspection as Hegemonic and Counter-Hegemonic Struggle in Prairie Districts Before 1940.” Canadian Ethnic Studies 33, 2 (2001): 31-51.

Makhoul, Anne. "Seeds of Promise: Grandview/?Uuqinak'uuh School in Vancouver.” Our Schools/Ourselves 11, 3 (Spring 2002): 39-50.

Mangan, J.A., ed. A Significant Social Revolution: Cross-Cultural Aspects of the Evolution of Compulsory Education. Portland, Oreg.: Woburn Press, 1994. (Includes a chapter on Canada)

Marker, M. "Indian Education in the Pacific Northwest: The Missing Research.” Tribal College Journal 4, 2 (1997): 17-21.

Marquis, Greg. “Going public: Atlantic Canadian academics and popular history.” Acadiensis 31, 1 (Autumn 2001): 146-51.

Marshall, Dominique. Aux origines sociales de l'État-Providence: familles québécoises, obligation scolaire, et allocations familiales, 1940-1955. Montréal: Presses de l’Université de Montréal, coll. “Trajectoires sociales”, 1998.

Marshall, Dominique. “Les familles québécoises et l'obligation scolaire, 19431960.” Lien social et politiques-RIAC 35 (printemps 1996): 13-21.

Martel, Angéline, et Daniel Villeneuve. “Idéologies de la nation, idéologies de l'éducation au Canada entre 1867 et 1960: le 'bénéfice du locuteur' majoritaire ou minoritaire.” Canadian Journal of Education 20, 3 (1995): 392-406. 
Martin, Michèle. "L'éducation des publics: la critique culturelle journalistique de Victor Barbeau.” Historical Studies in Education/Revue d'histoire de l'éducation 8, 2 (1996): 182-98.

Martin, Roger P. Les écoles de Rivière-Verte 1956-1995. RivièreVerte:[author], 1996.

Massolin, Philip A. "Modernization and Reaction: Postwar Evolutions and the Critique of Higher Learning in English-speaking Canada, 1945-1970.” Journal of Canadian Studies 36, 2 (Summer 2001): 130-63.

Masters, D.C. Henry John Cody: An Outstanding Life. Toronto: Dundurn Press, 1995.

Maxwell, Mary Percival, and James D. Maxwell. "Three Decades of Private School Females' Ambitions: Implications for Canadian elites.” Canadian Review of Sociology and Anthropology 31, 2 (1994): 139-67.

McAndrew, Marie, and Patricia LaMarre. "The Integration of Ethnic Minority Students Fifteen Years after Bill 101: Some Issues Confronting Montreal's French Language Public Schools." Canadian Ethnic Studies 28, 2 (1996): 40-63.

McGahan, Peter. The "Quiet Campus". A History of the University of New Brunswick in Saint John, 1959-1969. Fredericton: New Ireland Press, 1998.

McIntosh, Robert. "Constructing the Child: New Approaches to the History of Childhood in Canada.” Acadiensis 28, 2 (Spring 1999): 126-40. (Review essay)

McKeen, Carol A., and Alan J. Richardson. "Education, Employment and Certification: An Oral History of the Entry of Women into the Canadian Accounting Profession.” Business and Economic History 27, 2 (1998): $500-21$.

McKinnon, Frank. Church Politics and Education in Canada: The P.E.I. Experience. Calgary: Detselig Enterprises, 1995.

McLachlan, Elizabeth. With Unfailing Dedication: Rural Teachers in the War Years. Edmonton: NeWest Press, 2001.

McLaren, John P.S. “'New Canadians' or 'Slaves of Satan'? The Law and the Education of Doukhobor Children, 1911-1935.” In Children, Teachers, and Schools in the History of British Columbia, ed. Jean Barman, Neil Sutherland, and J. Donald Wilson. Calgary: Detselig Enterprises, 1995, 147-60.

McLaughlin, Kenneth. Waterloo: The Unconventional Founding of an Unconventional University. Waterloo, Ont.: University of Waterloo, 1997. 
McLean, Scott. "Objectifying and Naturalizing Individuality: A Study of Adult Education in the Canadian Arctic." Canadian Journal of Sociology 22, 1 (1997): 1-30.

McLean, Scott. "To Educate or Not to Educate? Canadian Discourses Concerning Inuit Schooling from the 1930s to the 1950s." Journal of Historical Sociology 8, 2 (1995): 182-97.

McLeod, Tommy. "McKee of Brandon College.” Manitoba History 40 (Autumn-Winter 2000-01): 33-46.

McMillan, Ann. "Women Students in Physics in Canada: A Decade of Progress.” Physics in Canada 52, 2 (Mar./Apr. 1996): 108-10, 113.

McNally, Vincent J. "Challenging the Status Quo: An Examination of the History of Catholic Education in British Columbia." Canadian Catholic Historical Association Historical Studies 65 (1999): 71-91.

McNaught, Kenneth. Conscience and History: A Memoir. Toronto: University of Toronto Press, 1999.

McQuaid, C.R. Early Island Schools and Schoolmasters. [Charlottetown]: Author, 2000.(P.E.I.)

Meehan, Peter M. "From College to University: The Basilian Fathers and Assumption, 1950-1963." Canadian Catholic Historical Association Historical Studies 64 (1997): 91-114.

Ménard, Sylvie. “Une politique de l'enfance délinquante: la mise en place de l'école de réforme des garçons de Montréal, 1850-1873.” Bulletin d'histoire politique 6, 2 (hiver 1998): 19-29.

Michaud, Nelson. "Les écoles d'Ontario ou le dilemme des conservateurs québécois: confrontation des principes nationalistes et de la réalité politique." Revue d'histoire de l'Amérique française 49, 3 (hiver 1996): 395-418. (Reg 17)

Mifflen, Jessie. “God Bless the Teacher.” Newfoundland Quarterly (SpringSummer 2000): 32-34.

Miles, Angela. "Learning from the Women's Movement in the Neo-Liberal Period.” In Learning for Life: Canadian Readings in Adult Education, ed. Sue M. Scott, Bruce Spencer, and Alan M. Thomas. Toronto: Thompson Educational Publishing, 1998, 250-58.

Millar, W.P.J. “'We wanted our children should have it better': Jewish Medical Students at the University of Toronto, 1910-51.” Journal of the Canadian Historical Association 11 (Edmonton 2000): 109-24.

Millar, W.P.J. and R.D. Gidney. “'Medettes’: Thriving or Just Surviving? Women Students in the Faculty of Medicine, University of Toronto, 1910-1951.” In Challenging Professions: Historical and Contemporary 
Perspectives on Women's Professional Work, ed. Elizabeth Smyth, Sandra Acker, Paula Bourne, and Alison Prentice. Toronto: University of Toronto Press, 1999, 215-33.

Miller, J.R. "Reading Photographs, Reading Voices: Documenting the History of Native Residential Schools." In Reading Beyond Words: Contexts for Native History, ed. Jennifer S.H. Brown and Elizabeth Vibert. Peterborough: Broadview Press, 1996.

Miller, J.R. Shingwauk's Vision: A History of Native Residential Schools. Toronto: University of Toronto Press, 1996.

Miller, James, and Edmund Danziger Jr. “'In the Care of Strangers': Walpole Island First Nation's Experiences with Residential Schools after the First World War.” Ontario History 92, 1 (2000): 71-88.

Miller, Mary Jane. "Where the Spirit Lives: An Influential and Contentious Television Drama about Residential Schools.” American Review of Canadian Studies 31, 1/2 (2001): 71-84.

Milloy, John. "A National Crime”: The Canadian Government and the Residential School System 1879-1986. Winnipeg: University of Manitoba Press, 1999.

Mills, Sean. "'Preach the World': Canadian Imperialism and Missionary Outreach at the Montreal Diocesan Theological College, 1892-1903.” Journal of the Canadian Church Historical Society 43, 1 (2001): 5-38.

Mills, Tracey. “A Home Away From Home: Newfoundland's School For The Deaf.” Downhomer 13, 10 (March 2001): 69-71.

Milot, Micheline and Jean-Pierre Proulx. Les attentes sociales à l'égard de la religion à l'école publique: rapport de recherche. Québec: Group de travail sur la place de la religion à l'école, 1999.

Mitchell, Tom. "The Manufacture of Souls of Good Quality: Winnipeg's 1919 National Conference on Canadian Citizenship, English-Canadian Nationalism, and the New Order after the Great War." Journal of Canadian Studies 31, 4 (1997): 5-28.

Monahan, Edward J. "University-Government Relations in Ontario: The History of a Buffer Body, 1958-1996.” Minerva 36, 4 (Winter 1998): $347-66$.

Moodley, Kogila A. "Multicultural Education in Canada: Historical Development and Current Status." In Handbook of Research on Multicultural Education, ed. James A. Banks. New York: Macmillan, 1995, 801-20.

Moody, Barry. "Esther Clark Goes to College.” Atlantis 20, 1 (Fall-Winter 1995): 39-48. 
Mook, Laurie. "Women at University: The Early Years.” Alberta History 44, 1 (Winter 1996): 9-14.

Moreau, Bernice. "Black Nova Scotian Women's Experience of Educational Violence in the Early 1900s: A Case of Colour Contusion.” Dalhousie Review 77, 2 (Summer 1997): 179-206.

Moreau, Josée. “La discipline au Collège Saint-Louis, 1949-1972.” Revue de la Société historique du Madawaska 25, 1/2 [sic., 2/3] (avr.-sept. 1997): 5-21.

Moss, Mark Howard. Manliness and Militarism: Educating Young Boys in Ontario for War. Don Mills: Oxford University Press, 2001.

Moulinet, Daniel. Les classiques païens dans les collèges catholiques? Le combat de Mgr. Gaume. Paris: Cerf, 1995.

Mujawamariya, Donatille. "Associate Teachers Facing Integration of Visible Minorities into the Teaching Profession in Francophone Ontario." Canadian Ethnic Studies 33, 2 (2001): 78-87.

Mulcahy, Dennis M. "Formal and informal education in Fair Haven, Placentia Bay, 1911-1958.” Newfoundland Studies 11 (Fall 1995): 283-307.

Munro, Margaret Findlay. Forward in Faith: Establishing the School of Nursing at the University of Prince Edward Island. Charlottetown: School of Nursing, University of Prince Edward Island, 2000.

Murphy, Michael F. "The Common School Amendment Acts of the 1830s and the Re-shaping of Schooling in London, Upper Canada.” Historical Studies in Education/Revue d'histoire de l'éducation 8, 2 (1996): 147-66.

Murphy, Michael F. "The Formation of Roman Catholic Schools in London, Ontario, 1850-1871.” Canadian Catholic Historical Association Historical Studies 63 (1997): 59-79.

Murphy, Michael F. "Unmaking and Remaking the 'One Best System': London, Ontario, 1852-1860.” History of Education Quarterly 37, 3 (Fall 1997): 291-310.

Murray, Heather. “Great Works and Good Works: The Toronto Women's Literary Club, 1853-77.” Historical Studies in Education/Revue d'histoire de l'éducation 11, 1 (Spring 1999): 75-95.

Murray, Heather. “'We Strive for the Good and Beautiful': Literary Studies at the Margaret Eaton School of Literature and Expression.” In Working in English: History, Institution, Resources, ed. Heather Murray. Toronto: University of Toronto Press, 1996, 46-67.

Murray, Heather. Working in English: History, Institutions, Resources. Toronto: University of Toronto Press, 1996. 
Myers, Tamara, and Joan Sangster. "Retorts, Runaways and Riots: Patterns of Resistance in Canadian Reform Schools for Girls, 1930-60.” Journal of Social History 34, 3 (Spring 2001): 669-98.

Nakhaie, M. Reza, and James Curtis. "Effects of Class Positions of Parents on Educational Attainment of Daughters and Sons.” Canadian Review of Sociology and Anthropology/Revue canadienne de sociologie et d'anthropologie 35, 4 (Nov. 1998): 483-516.

Nash, Roy. "The Educated Habitus, Progress at School, and Real Knowledge.” Interchange 33, 1 (2002): 27-48.

Neatby, Nicole. Carabins ou activistes?: l'idéalisme et la radicalisation de la pensée étudiante à l'Université de Montréal au temps du duplessisme. Montréal et Kingston: McGill-Queen’s University Press, 1999.

Neatby, Nicole. "Student Leaders at the University of Montreal During the Early 1950s: What Did Catholics Want?” Canadian Catholic Historical Association Historical Studies 62 (1996): 73-88.

Nelles, Wayne. “Citizen Diplomacy, Internationalism and Anglo-American Educational Relations, 1919-1946: Canada in a 'North Atlantic Triangle'.” International Journal of Canadian Studies 22 (Fall 2000): 135-62.

Nelles, Wayne. "Mongolian-Canadian Education, Training, and Research Cooperation: A Brief History, 1973-2000.” Canadian and International Education 29, 2 (Dec. 2000): 91-106.

Nelson, Wendie. “' Rage against the Dying of the Light': Interpreting the Guerre des Éteignoirs.” Canadian Historical Review 81, 4 (2000): 55181.

Neufeldt, Harvey. “'You've Changed Too’: The Education of the Yarrow Mennonite Community, 1928-1960.” Historical Studies in Education/Revue d'histoire de l'éducation 7, 1 (1995): 71-96.

"New Brunswick high school entrance examinations — June 1926." Reflections (NBTA) 18, 1 (Fall 2000): 220-21.

Norman, Marion. "Making a Path by Walking: Loretto Pioneers Facing the Challenges of Catholic Education on the North American Frontier." Canadian Catholic Historical Association. Historical Studies 65 (1999): 92-106.

Norton, Wayne. “The Cache Creek Provincial Boarding School 1874-1890.” British Columbia Historical News 29, 2 (Spring 1996): 30-33, 40.

O’Donoghue, Thomas A. "Catholicism and the Curriculum: The Irish Secondary School Experience, 1922-62.” Historical Studies in Education/Revue d'histoire de l'éducation 10, 1\&2 (Spring/printemps \& Fall/automne 1998): 140-58. 
O’Grady, Jean. Margaret Addison: A Biography. Montreal and Kingston: McGill-Queen’s University Press, 2001.

Osborne, Ken. “Citizenship Education and Social Studies.” In Trends and Issues in Canadian Social Studies, ed. Ian Wright and Alan Sears. Vancouver: Pacific Educational Press, 1997, 39-67.

Osborne, Ken. "Education is the Best National Insurance: Citizenship Education in Canadian Schools, Past and Present.” Canadian and International Education 25, 2 (Dec. 1996): 31-58.

Osborne, Ken. "One Hundred Years of History Teaching in Manitoba Schools, Part I: 1897-1927.” Manitoba History 26 (1998/1999): 3-25.

Osborne, Ken. ““Our History Syllabus Has Us Gasping’: History in Canadian Schools - Past, Present and Future.” Canadian Historical Review 81, 3 (September 2000): 404-35.

Osborne, Ken. "Public Schooling and Citizenship Education in Canada." Canadian Ethnic Studies/Études Ethniques au Canada 32, 1 (2000): 8-37.

Osborne, Ken. “The Changing Status of Canadian History in Manitoba. Canadian Social Studies.” The History and Social Science Teacher 31, 1 (Fall 1996): 28-30.

Osborne, Ken. “What's Happening to Canadian History?” Manitoba Social Science Teacher 22, 3 (Mar. 1996): 4-7.

Osborne, Kenneth W. In Defence of History: Teaching the Past and the Meaning of Democratic Citizenship. Toronto: Our Schools/Our Selves Foundation, 1995.

O’Sullivan, Brian. "Global Change and Educational Reform in Ontario and Canada.” Canadian Journal of Education 24, 3 (1999): 311-25. (Last 30 years)

Ouellet, Danielle. Histoires de chimistes. L'École supérieure de chimie de l'Université Laval 1920-1937. S.l., Presses de l’Université Laval, 1996.

Ouellet, Fernand. “Démographie, développement économique, fréquentation scolaire et alphabétisation dans les populations acadiennes des Maritimes avant 1911: une perspective régionale comparative.” Acadiensis 26,1 (automne 1996): 3-31.

Overton, James. "Moral Education of the Poor: Adult Education and Land Settlement Schemes in Newfoundland in the 1930s." Newfoundland Studies 11 (Fall 1995): 250-82.

Pachai, Bridglal. Education in Nova Scotia: The African Nova Scotian Experience. Truro, N.S.: Nova Scotia Teachers College, 1997. 
Patenaude, Branwen C. "White Gloves and Parasols." British Columbia Historical News 31, 3 (Summer 1998): 2-5. (Teaching in the Cariboo, 1910-55)

Patrick, Donna. “Minority Language Education and Social Context.” Études Inuit Studies 18, 1 \& 2 (1994): 183-200.

Patrick, Donna, and Perry Shearwood. “The Roots of Inuktitut-Language Bilingual Education.” Canadian Journal of Native Studies/La revue canadienne de études autochtones 19, 2 (1999): 249-62.

Peake, Frank A. "Reflections on Anglican Theological Education.” Journal of the Canadian Church Historical Society 41, 2 (Fall 1999): 99-125.

Pedersen, Diana. Changing Women, Changing History: A Bibliography of the History of Women in Canada. $2^{\text {nd }}$ ed. Women's Experience Series 9. Ottawa: Carleton University Press, 1996.

Peterat, Linda, and Mary Leah DeZwart. An Education for Women: The Founding of Home Economics Education in Canadian Public Schools. Charlottetown, P.E.I.: Home Economics Publishing Collective, University of Prince Edward Island, 1995.

Petrina, Stephen. “Getting a Purchase on 'The School of Tomorrow' and Its Constituent Commodities: Histories and Historiographies of Technologies.” History of Education Quarterly 42, 1 (Spring 2002): 75111.

Phillips, Jim. “The Disquisitions of Learned Judges: Making Manitoba Lawyers, 1885-1931.” In Essays in the History of Canadian Law: v.8, ed. G. Blaine Baker and Jim Phillips. Toronto: University of Toronto Press, 1999.

Pichette, Robert. "Les Soeurs de la Congrégation de Notre-Dame, premières éducatrices en Acadie.” Les Cahiers de la Société historique acadienne 29, 3 (juillet-sept. 1998): 125-42.

Pickles, Katie. "Colonial Counterparts: The First Academic Women in AngloCanada, New Zealand and Australia.” Women's Historical Review 10, 2 (2001): 273-97.

Pilote, Annie. "La question scolaire et le développement démocratique en Acadie.” égalité - revue acadienne d'analyse politique 43 (printemps 1998): 131-47.

Plante, Lucienne. "La fondation de l'enseignement classique féminin au Québec.” Dans L'histoire de la culture et de l'imprimé: hommages à Claude Galarneau, dir. Yvan Lamonde et Gilles Gallichan. Sainte-Foy: Presses de l’Univerisité Laval, 1996, 91-106. 
Pletsch, Vera C. Not Wanted in the Classroom: Parent Associations and the Education of Trainable Retarded Children in Ontario. London, Ontario: The Althouse Press, 1997.

Poelzer, Irene. "Fr. Henry Carr and the Federated Model.” In The Basilian Way of Life and Higher Education, ed. John Thompson. Saskatoon: St. Thomas More College, 1995, 57-75.

Poonwassie, Deo H., and Ann Poonwassie, eds. Adult Education in Manitoba: Historical Aspects. Mississauga: Canadian Educators’ Press, 1997.

Prentice, Alison. "Laying Siege to the History Professoriate.” In Creating Historical Memory: English-Canadian Women and the Work of History, ed. B. Boutilier and A. Prentice. Vancouver: UBC Press, 1997, 197-232.

Prentice, Alison. “Mapping Canadian Women’s Teaching Work: Challenging the Stereotypes." In Education into the Twenty-First Century: Dangerous Terrain for Women? ed. Alison Mackinnon, Inga Elgqvist-Saltzman, and Alison Prentice. London: The Falmer Press, 1998, 31-42.

Prentice, Alison. "The Early History of Women in University Physics: A Toronto Case Study.” Physics in Canada 52, 2 (Mar./Apr. 1996): 94-96, 100.

Prentice, Alison. The School Promoters: Education and Social Class in MidNineteenth Century Upper Canada. Don Mills, Ont.: Oxford University Press, 1999.

Prentice, Alison. "Vivian Pound was a Man? The Unfolding of a Research Project." Historical Studies in Education/Revue d'histoire de l'éducation 13, 2 (2001): 99-112.

Prentice, Alison. "Workers, Professionals, Pilgrims: Tracing Canadian Women's Teachers' Histories.” In Telling Women's Lives: Narrative Inquiries in the History of Women's Education, ed. Kathleen Weiler and Sue Middleton. (Buckingham, UK: Open University Press, 1999): 25-42.

Prentice, Susan, and Jackie Stalker, eds. The Illusion of Inclusion: Women in Post Secondary Education. Toronto: James Lorimer, 1997.

Proulx, Jean-Pierre. “L’évolution de la législation relative au système électoral scolaire québécois (1829-1989).” Historical Studies in Education/Revue d'histoire de l'éducation 10, 1/2 (1998): 20-47.

Pue, W. Wesley. "British Masculinities, Canadian Lawyers: Canadian Legal Education 1900-1930,” in Misplaced Traditions: British Lawyers, Colonial People. Annandale, NSW, Aus.: Federation Press, 1999.

Pue, W. Wesley. Law School: The Story of Legal Education in British Columbia. Vancouver: University of British Columbia Faculty of Law, 1995. 
Raibmon, Paige. ““A New Understanding of Things Indian’: George Raley’s Negotiation of the Residential School Experience.” BC Studies 110 (Summer 1996): 69-96.

Raibmon, Paige. “'In loco parentis’: G.H. Raley and a Residential School Philosophy." Journal of the Canadian Church Historical Society 38, 1 (Apr. 1996): 29-52.

Raptis, Helen, and Thomas Fleming. “Unraveling Multicultural Education's Meanings: An Analysis of Core Assumptions Found in Academic Writings in Canada and the United States, 1981-1997.” Journal of Educational Thought 32, 2 (Aug. 1998): 169-94.

Reford, Alexander. "St. Michael's College at the University of Toronto, 19581978: the Frustrations of Federation." Canadian Catholic Historical Association Historical Studies 61 (1995): 171-94.

Regnier, Robert. "The Sacred Circle: An Aboriginal Approach to Healing Education at an Urban High School.” In First Nations Education in Canada: The Circle Unfolds, ed. Jean Barman and Marie Battiste. Vancouver: University of British Columbia Press, 1995, 313-28.

Reynolds, C. "The Educational System.” In Feminist Issues: Race, Class, and Sexuality, ed. N. Mandell. $3^{\text {rd }}$ ed. Toronto: Prentice-Hall, 2001, 242-59.

Reynolds, Cecilia. "In the Right Place at the Right Time: Rules of Control and Woman's Place in Ontario Schools, 1940-1980.” Canadian Journal of Education 20, 2 (Spring 1995): 129-45.

Reynolds, Cecilia, and Harry Smaller. "Gender Relations Among Ontario Teachers: A Study of Ontario Teachers in the 1930s.” McGill Journal of Education 31, 1 (1996): 39-56.

Reynolds, Cecilia and Beth Young. Women and Leadership in Canadian Education. Calgary: Detselig Enterprises, 1995.

Richards, Carole. "Le rapport de la Commission de planification académique de l'Université de Moncton et l'enseignement des sciences au Collège Saint-Louis au tournant des années 70." Revue de la Société historique du Madawaska 25, 1/2 [sic., 2/3] (avr.-sept. 1997): 36-47.

Richardson, John G. "Historical Context, Professional Authority and Discourses of Risk: Child Guidance and Special Education.” Teachers College Record 104, 3 (Apr. 2002): 563-85.

Richardson, Theresa. "Ambiguities in the Lives of Children: Postmodern Views on the History and Historiography of Childhood in English Canada.” Paedagogica Historica 32, 2 (1996): 363-93.

Ricker, Eric W. and B. Anne Wood, eds. Historical Perspectives on Educational Policy in Canada: Issues, Debates, and Case Studies. Toronto: Canadian Scholars' Press in association with the Canadian 
History of Education Association/Association canadienne d'histoire de l'éducation, 1995.

Rink, Deborah. Spirited Women: A History of Catholic Sisters in British Columbia. Vancouver: Sisters Association of Vancouver Archdiocese, 2000.

Robertson, Susan, and Harry Smaller, eds. Teachers' Political Activism in the 1990s. Toronto: James Lorimer, 1996.

Robillard, Denise. “L’enseignement religieux dans l'école québécoise (19611995): aperçu des lois et des règlements relatifs à l'enseignement religieux dans les écoles.” Dans Enseigner le catéchisme: autorités et institutions, XVIe-XXe siècles, dir. Raymond Brodeur et Brigitte Caulier. Québec/Paris: Presses de l’Université Laval/Éditions du Cerf, 1997, 389401.

Roper, Henry. “A ‘High Anglican Pagan’ and his pupil: Charles G. D. Roberts, Robert Norwood and the development of a Nova Scotian literary tradition, 1885-1932.” Dalhousie Review 75, 1 (1995): 51-73.

Roper, Henry. "Haliburton and King’s College.” In The Haliburton bicentenary chaplet, ed. Richard A. Davies. Wolfville, N.S.: Gaspereau Press, 1997, 85-100.

Ross, Alexander M., and Terence A. Crowley. The College on the Hill: A New History of the Ontario Agricultural College, 1874-1999. Rev. ed. Toronto: Dundurn Press, 1999.

Ross, Campbell A. “'Only in Canada? Pity.' The Sad Fate of Educational Conservatism in Canada." Historical Studies in Education/Revue d'histoire de l'éducation 8, 2 (Fall/automne 1996): 226-36.

Ross, Sally. Les écoles acadiennes en Nouvelle-Écosse, 1758-2000. Moncton: Centre d'études acadiennes, 2001.

Rousmaniere, Kate. "Teachers' Work and the Social Relations of School Space in Early-Twentieth-Century North American Urban Schools." Historical Studies in Education/Revue d'histoire de l'éducation 8, 1 (Spring/printemps 1996): 42-64.

Saint-Cyr, Gérard. L'école et l'industrie des pêches du Nouveau-Brunswick. Lévis: Éditions Faye, 1998.

Sanche, Margaret. "A Matter of Identity: St. Thomas More College at the University of Saskatchewan, 1961-1977." Canadian Catholic Historical Association Historical Studies 61 (1995): 195-214.

Sanche, Margaret. "Weavings: The Founding and Early Years of St. Thomas More College at the University of Saskatchewan." In The Basilian Way of Life and Higher Education, ed. John Thompson. Saskatoon: St. Thomas More College, 1995, 87-108. 
Satzewich, Vic, and Linda Mahood. "Indian Agents and the Residential School System in Canada, 1946-1970.” Historical Studies in Education/Revue d'histoire de l'éducation 7, 1 (1995): 45-70.

Sauvé, Madeleine. La Faculté de théologie de l'Université de Montréal: mémoire et histoire, 1967-1997. Saint-Laurent: Bellarmin, 2001.

Sauvé, Madeleine. L'Institut supérieur de sciences religieuses de la Faculté de théologie de l'Université de Montréal. Montréal: Bellarmin, 1995.

Savard, Pierre. "Pour l'histoire des jeunes.” Les cahiers d'histoire du Québec au XXe siècle 2 (été 1994): 119-31.

Sawyer, Don. Tomorrow is School and I'm Sick to the Heart Thinking About It. Rev. ed. [Mill Bay, B.C.]: Bendall Books, 1998. (High school teacher's autobiography, Newfoundland).

Schütze, Hans Georg, et al. Post-Secondary Education in British Columbia, 1989-1998: The Impact of Policy and Finance on Access, Participation, and Outcomes. Vancouver: Centre for Policy Studies in Higher Education and Training, University of British Columbia, 2001.

Selles, Johanna M. Methodists and Women's Education in Ontario, 18361925. Montreal and Kingston: McGill-Queen's University Press, 1996.

Selman, Gordon, et al. The Foundations of Adult Education in Canada. $2^{\text {nd }}$ ed. Toronto: Thompson Educational Publishing, 1998.

Selman, Gordon R. Adult Education in Canada: Historical Essays. Toronto: Thompson Educational Publishing, 1995.

Senkpiel, Aron. "Post-Secondary Education in the Yukon: The Last Thirty Years.” Northern Review 12/13 (Summer 1994/winter 1994): 90-100.

Sethna, Christabelle. "The Cold War and the Sexual Chill: Freezing Girls out of Sex Education.” Canadian Woman Studies/les cahiers de la femme 17, 4 (Winter 1998): 57-61.

Sethna, Christabelle. "Men, Sex, and Education: The Ontario Women's Temperance Union and Children's Sex Education, 1900-20.” Ontario History 88, 3 (Sept. 1996): 185-206.

Sethna, Christabelle. "Nature, Natural, Naturalist: Nature Study and the Teaching of Biological Reproduction in Ontario, 1900-1930.” Canadian Journal of Human Sexuality 3, 3 (Fall 1994): 191-98.

Shamai, Shmuel. "Jewish Resistance to Christianity in the Ontario Public Education System." Historical Studies in Education/Revue d'histoire de l'éducation 9, 2 (1997): 251-55. 
Sharp, Rosalie, Irving Abella, and Edwin Goodman. Growing Up Jewish: Canadians Tell Their Own Stories. Toronto: McClelland and Stewart, 1997.

Shearmur, Richard G. "A Geographical Perspective on Education and Jobs Employment Growth and Education in the Canadian Urban System, 19811994." Canadian Journal of Regional Science 21, 1 (Spring 1998): 15-48.

Sheehan, Nancy M. "World War I and Educational Policy in English Canada.” In Historical Perspectives on Educational Policy in Canada: Issues, Debates and Case Studies, ed. E.W. Ricker and B. Anne Wood. Toronto: Canadian Scholars’ Press, 1995, 253-79.

Sheehan, Nancy M. and J. Donald Wilson. "From Normal School to University to the College of Teachers: Teacher Education in British Columbia." Journal of Education for Teaching 20, 1 (Jan. 1994): 23-37.

Sheets-Pyenson, Susan. John William Dawson: Faith, Hope, and Science. Montreal and Kingston: McGill-Queen's University Press, 1996.

Siegel, Linda S., and Stewart Ladyman. A Review of Special Education in British Columbia. Victoria: Ministry of Education, 2000.

Skilling, H. Gordon. The Education of a Canadian: My Life as a Scholar and Activist. Ottawa: Carleton University Press, 1999.

Smith, Donald. "Elizabeth Barrett.” Alberta History 46, 4 (Autumn 1998): 1928. [Indian mission teacher, 1875-88]

Smith, Donald B. "The Steinhauer Brothers: Education and Self-Reliance.” Alberta History 50, 2 (Spring 2002): 2-10.

Smyth, Elizabeth. “"The True Standing of Catholic Higher Educational Institutions' of English Canada: the 1901 Falconio Survey.” Canadian Catholic Historical Association Historical Studies 66 (2000): 114-31.

Smyth, Elizabeth, et al., eds. Challenging Professions: Historical and Contemporary Perspectives on Women's Professional Work. Toronto: University of Toronto Press, 1999.

Sonser, Anna. "Literary Ladies and The Calliopean: English Studies at the Burlington Ladies' Academy (1846-1851)." University of Toronto Quarterly 64, 3 (1995): 368-80.

Spafford, Shirley. No Ordinary Academics: Economics and Political Science at the University of Saskatchewan, 1910-1960. Toronto: University of Toronto Press, 2000.

Sproule-Jones, Megan. "Crusading for the Forgotten: Dr. Peter Bryce, Public Health, and Prairie Native Residential Schools.” Canadian Bulletin of Medical History 13, 2 (1996): 199-224. 
Stairs, Arlene. "Learning Processes and Teaching Roles in Native Education: Cultural Base and Cultural Brokerage.” In First Nations Education in Canada: The Circle Unfolds, ed. Jean Barman and Marie Battiste. Vancouver: University of British Columbia Press, 1995), 139-53.

Stalker, Jacqueline, and Susan Prentice, eds. The Illusion of Inclusion: Women in Post-Secondary Education. Halifax: Fernwood Books, 1998.

Stalker, Joyce. "Women in the History of Adult Education: Misogynist Responses to Our Participation.” In Learning for Life: Canadian Readings in Adult Education, ed. Sue M. Scott, Bruce Spencer, and Alan M. Thomas. Toronto: Thompson Educational Publishing, 1998, 238-49.

Stanley, Timothy J. "Schooling, White Supremacy, and the Formation of a Chinese Merchant Public in British Columbia.” BC Studies 107 (Autumn 1995): 3-29.

Stanley, Timothy J. "White Supremacy and the Rhetoric of Educational Indoctrination." In Children, Teachers, and Schools in the History of British Columbia , ed. Jean Barman, Neil Sutherland and J. Donald Wilson. Calgary: Detselig Enterprises, 1995.

Stanley, Timothy J. "Why I Killed Canadian History: Conditions for an AntiRacist History in Canada.” Histoire sociale/Social History 33, 65 (May 2000): 79-104.

Stebner, Eleanor. “The Education of Stanley Howard Knowles.” Manitoba History 36 (1998/1999): 41-51.

Steele, John W. History of the Faculty of Pharmacy 1899-1999. Winnipeg: University of Manitoba, Faculty of Pharmacy, 1999.

Steiner, Samuel J. Lead Us On: A History of Rockway Mennonite Collegiate, 1945-1995. Kitchener: Rockway Mennonite Collegiate, 1995.

Stephen, Jennifer, and Gaetan Beaudet. "Survey of Trends in Adult Education, 1985-1995, and Perspectives for the Twenty-First Century." Canadian Woman Studies/les cahiers de la femme 17, 4 (Winter 1998): 143-48.

Stephenson, Penelope. “'Mrs.Gibson Looks as if she was ready for the end of term': The Professional Trials and Tribulations of Rural Teachers in British Columbia's Okanagan Valley in the 1920s.” In Children, Teachers, and Schools in the History of British Columbia, ed. Jean Barman, Neil Sutherland and J. Donald Wilson. Calgary: Detselig Enterprises, 1995, 235-57.

Sterling, Shirley. "Quaslametko and Yetko: Two Grandmother Models for Contemporary Native Education Pedagogy.” In First Nations Education in Canada: The Circle Unfolds, ed. Jean Barman and Marie Battiste. Vancouver: University of British Columbia Press, 1995, 113-23. 
Stevens, Julie. "Letters from Montney: An Insight Into the Rural Teaching Experience in Early $20^{\text {th }}$ Century British Columbia." British Columbia Historical News 34, 2 (2001): 17-25.

Storm, Christine, ed. Liberal Education and the Small University in Canada. Montreal and Kingston: McGill-Queen's University Press, 1996.

Strimelle, Véronique. "Les origines des premières institutions d'enfermement pour filles au Québec (1857-1869). Émergence de nouveaux enjeux politiques?” Bulletin d'histoire politique 6, 2 (hiver 1998): 30-39.

Strong-Boag, Veronica. "Claiming a Place in the Nation: Citizenship Education and the Challenge of Feminists, Natives and Workers in PostConfederation Canada." Canadian and International Education 25, 2 (1997): 128-45.

Strong-Boag, Veronica. "Long Time Coming: The Century of the Canadian Child?” Journal of Canadian Studies/Revue d'études canadiennes 35, 1 (2000): 124-37.

Stuart, Meryn. "War and Peace: Professional Identities and Nurses' Training, 1914-1930.” In Challenging Professions: Historical and Contemporary Perspectives on Women's Professional Work, ed. Elizabeth Smyth, Sandra Acker, Paula Bourne, and Alison Prentice. Toronto: University of Toronto Press, 1999, 171-93.

Sturhelm, Yvonne. "Just or Unjust? The 1895 Dismissal of School Principal Joseph Irwin.” Okanagan History 62 (1998): 44-53.

Sutherland, Neil. "Children and Families Enter History's Main Stream.” Canadian Historical Review 78, 3 (Sept. 1997): 379-84. (Introduction, special issue on Childhood and Family in the Twentieth Century)

Sutherland, Neil. Growing Up: Childhood in English Canada from the Great War to the Age of Television. Toronto: University of Toronto Press, 1997.

Sweet, Brad. "Father François Lejamtel: Ecclesiastical Education at Arichat (1792-1819).” Cahiers de la Société historique acadienne 31, 3/4 (2000): 175-94.

Sweet, Lois. God in the Classroom: The Controversial Issue of Religion in Canada's Schools. Toronto: McClelland and Stewart, 1997.

Tardif, Maurice, et Joséphine Mukamurera. "Comment naît un noveau groupe professionel en milieu scolaire? Le cas des orthopédagogues au Québec de 1960 à nos jours." Historical Studies in Education/Revue d'histoire de l'éducation 11, 1 (1999): 33-58.

Tavares, Antonio (Tony) J. “From Heritage to International Languages: Globalism and Western Canadian Trends in Heritage Language Education.” Canadian Ethnic Studies/Études Ethniques au Canada 32, 1 (2000): 156-71. 
Taylor, Alison. The Politics of Educational Reform in Alberta. Toronto: University of Toronto Press, 2001.

Taylor, Donald M. "Toward Full Empowerment in Native Education: Unanticipated Challenges.” Canadian Journal of Native Studies 21, 1 (2001): 45-56.

Taylor, John. "Non-Native Teachers Teaching in Native Communities.” In Jean Barman and Marie Battiste, First Nations Education in Canada: The Circle Unfolds (Vancouver: University of British Columbia Press, 1995), 224-42.

Thomas, Karl-Xavier. “Attendre? Qui Reculer? Jamais! Les étudiants de l'Université de Montréal et le combat pour la gratuité scolaire sous le gouvernement Lesage.” Bulletin du RCHTQ 26, 1 (printemps 2000): 3-18.

Thompson, Brian E. “Studio Pedagogy for Engineering Design.” The International Journal of Engineering Education 18, 1 (2002): 39-49.

Thomson, Gerald E. “A Fondness for Charts and Children: Scientific Progressivism in Vancouver Schools 1920-50." Historical Studies in Education/Revue d'histoire de l'éducation 12, 1/2 (Spring 2000): 111-28.

Timmons, V., and C.L. Wood. "An oral history of gifted education in Prince Edward Island.” Agate 14, 2 (2000): 83-90.

Titley, E. Brian. “A Troubled Legacy: The Catholic Church and Indian Residential Schooling in Canada.” In The Colonial Experience in Education: Historical Issues and Perspectives, ed. A. Novox, M. Depaepe, and E.V. Johanningmeier.. Paedagogica Historica Supplementary Series, 1 (1995,), 335-52.

Tompkins, Joanne. Teaching in a Cold and Windy Place: Change in an Inuit School. Toronto: University of Toronto Press, 1999.

Townsend, Lucy, and Elizabeth Johnson. "Life-Writing and Journals in the History of Education.” Historical Studies in Education/Revue d'histoire de l'éducation 8, 2 (1996): 212-25.

Trevithick, Scott R. "Native Residential Schooling in Canada: A Review of Literature.” Canadian Journal of Native Studies/La Revue canadienne des études Autochtones 18, 1 (1998): 49-86.

Trudel, Jean-Louis. "Born in War: Canada’s Postwar Engineers and Toronto’s Ajax Division.” Scientia Canadensis 21, 50 (1997): 3-27.

Turcotte, Paul André. "The Assertion of Cultural Identity and Integration into the Modern World in Secondary Education in Quebec (1920-1990).” McGill Journal of Education 32, 1 (1997): 7-34.

Turmel, André. "Historiography of Children in Canada." Paedagogica Historica 33, 2 (1997): 509-20. 
Twohig, Peter L. Challenge and Change: A History of the Dalhousie School of Nursing, 1949-1989. Halifax: Fernwood Publishing and Dalhousie University, 1998.

Twohig, Peter L. ““To Produce an Article We Are Not Capable at Present of Producing': The Evolution of the Dalhousie University School of Nursing, 1946-1956.” Nova Scotia Historical Review 15, 2 (1995): 2642.

Vallières, Catherine. “'Apprendre à bien mourir’: les écoliers et la mort au Québec, 1853-1963.” Études d'histoire religieuse 65 (1999): 29-52.

Van Brummelen, Harro. "Religiously-Based Schooling in British Columbia: An Overview of Research." Journal of the Canadian Church Historical Society 38, 1 (Apr. 1996): 101-22.

Varga, Donna. Constructing the Child: A History of Canadian Day Care. Toronto: James Lorimer and Co., 1997.

Verrette, Michel. "Le retard de l'alphabétisation au Québec.” Dans L'histoire de la culture et de l'imprimé: hommages à Claude Galarneau, dir. Yvan Lamonde et Gilles Gallichan. (Sainte-Foy: Presses de l'Univerisité Laval, 1996): 109-121.

Von Heyking, Amy. "Selling Progressive Education to Albertans, 1935-53." Historical Studies in Education/Revue d'histoire de l'éducation 10, 1/2 (1998): 67-84.

Waite, Peter B. The Lives of Dalhousie University, Volume 2, 1925-1980: The Old College Transformed. Montreal and Kingston: McGill-Queen's University Press, 1998.

Wanner, Richard A. "A Matter of Degree(s): Twentieth-Century Trends in Occupational Status Returns to Educational Credentials in Canada." Canadian Review of Sociology and Anthropology/Revue canadienne de sociologie et d'anthropologie 37, 3 (2000): 313-44.

Wanner, Richard A. "Expansion and Ascription: Trends in Educational Opportunity in Canada, 1920-1994." Canadian Review of Sociology and Anthropology/Revue canadienne de sociologie et d'anthropologie 36, 3 (1999): 409-42.

Warner, Barb. George Jay School 1909: A Glance Back at Public School Education. Victoria: Desktop Publishing, 1998. (B.C.)

Wein, Carol Anne, and Curt Dudley-Marling. "Limited Vision: The Ontario Curriculum and Outcomes Based Learning." Canadian Journal of Education 23, 4 (1998): 405-21.

Weiss, Gillian M., ed. Trying to Get It Back: Indigenous Women, Education and Culture. Waterloo: Wilfrid Laurier University Press, 2000. (Canadian and Australian women) 
Westfall, William. The Founding Moment: Church, Society, and the Construction of Trinity College. Montreal and Kingston: McGill-Queen's University Press, 2002.

White, Anne. "Emily Spencer Kerby: Pioneer Club Woman, Educator, and Activist.” Alberta History 46, 3 (Summer 1998): 1-9.

White, Clinton O. "German Catholic Parochial Schools in St. Peter's Colony: Their Buildings, Equipment and Finances.” Saskatchewan History 48, 2 (Fall 1996): 26-47.

White, Clinton O. "The German Catholic Parochial Schools of Saskatchewan's St. Peter's Colony, 1903-1934: Their Teachers, Curriculum, and Quality of Instruction.” Prairie Forum 24, 1 (Spring 1999): 65-90.

White, Clinton O. "The Politics of Elementary Schools in a GermanAmerican Roman Catholic Settlement in Canada's Province of Saskatchewan, 1903 - 1925.” Great Plains Research 7, 2 (1997): 251-72.

White, Richard. "Professionals and Academics: Relations between the School of Practical Science and the University of Toronto, 1878-1906." Historical Studies in Education/Revue d'histoire de l'éducation 13, 2 (2001): 147-64.

White, Richard. The Skule Story: The University of Toronto Faculty of Applied Science and Engineering, 1873-2000. Toronto: University of Toronto Press, 2000.

Wilhelmy, Albert, Pascal Côté, et Yvon Gasse. Faculté des sciences de l'administration, 1924-1999: un héritage porteur d'avenir. Québec: Université Laval, Faculté des sciences de l'administration, Centre des relations avec le milieu, 1999.

Wilson, Robert S. “'Conservative but not contentious': the early years of the United Baptist Bible Training School.” In Revivals, Baptists, and George Rawlyk: a memorial volume, ed. Daniel C. Goodwin. Wolfville: Acadia Divinity College, 2000, 133-51.

Wood, B. Anne. "Pictou Academy: Promoting 'Schooled Subjectivities' in $19^{\text {th }}$-Century Nova Scotia.” Acadiensis 28, 2 (Spring 1999): 41-57.

Wood, B. Anne. "Schooling / credentials for professional advancement: a case study of Pictou Presbyterians." In The Contribution of Presbyterianism to the Maritime Provinces of Canada, ed. Charles H. H. Scobie and George A. Rawlyk. Montreal and Kingston: McGill-Queen's University Press, 1997, 54-72.

Wotherspoon, Terry. "The Incorporation of Public School Teachers into the Industrial Order: British Columbia in the First Half of the Twentieth Century.” Studies in Political Economy 46 (1995): 119-51. 
Wotherspoon, Terry. “Occupational Divisions and Struggles for Unity Among British Columbia’s Public School Teachers.” BC Studies 107 (Autumn 1995): 30-59.

Wotherspoon, Terry. The Sociology of Education in Canada: Critical Perspectives. Toronto: Oxford University Press, 1998.

Woywitka, Anne. “Golden Rule Days.” Alberta History 46, 2 (1998), 10-19.

Zeller, Suzanne. "Roads Not Taken: Victorian Science, Technical Education, and Canadian Schools, 1844-1913." Historical Studies in Education/Revue d'histoire de l'éducation 12, 1/2 (Spring 2000): 1-28.

Zilber, Julie. “Conceiving a Trans-National Education Project.” Education Canada 42, 1 (2002): 36-9. (Pacific Salmon Summit) 